University of Wollongong

Research Online

Faculty of Business - Papers (Archive)

Faculty of Business and Law

$1-1-2016$

How to improve firm performance using big data analytics capability and business strategy alignment?

\author{
Shahriar Akter \\ University of Wollongong, sakter@uow.edu.au \\ Samuel Fosso Wamba \\ Toulouse Business School, samuel.fosso.wamba@neoma-bs.fr \\ Angappa Gunasekaran \\ University of Massachusetts \\ Rameshwar Dubey \\ Constituent Of Symbiosis International University \\ Stephen J. Childe \\ Plymouth Business School
}

Follow this and additional works at: https://ro.uow.edu.au/buspapers

Part of the Business Commons

Research Online is the open access institutional repository for the University of Wollongong. For further information contact the UOW Library: research-pubs@uow.edu.au 


\title{
How to improve firm performance using big data analytics capability and business strategy alignment?
}

\author{
Abstract \\ The recent interest in big data has led many companies to develop big data analytics capability (BDAC) in \\ order to enhance firm performance (FPER). However, BDAC pays off for some companies but not for \\ others. It appears that very few have achieved a big impact through big data. To address this challenge, \\ this study proposes a BDAC model drawing on the resource-based theory (RBT) and the entanglement \\ view of sociomaterialism. The findings show BDAC as a hierarchical model, which consists of three \\ primary dimensions (i.e., management, technology, and talent capability) and 11 subdimensions (i.e., \\ planning, investment, coordination, control, connectivity, compatibility, modularity, technology \\ management knowledge, technical knowledge, business knowledge and relational knowledge). The \\ findings from two Delphi studies and 152 online surveys of business analysts in the U.S. confirm the value \\ of the entanglement conceptualization of the higher-order BDAC model and its impact on FPER. The \\ results also illuminate the significant moderating impact of analytics capability-business strategy \\ alignment on the BDAC-FPER relationship.

\section{Disciplines \\ Business}

\section{Publication Details} \\ Akter, S., Fosso Wamba, S., Gunasekaran, A., Dubey, R. \& Childe, S. J. (2016). How to improve firm \\ performance using big data analytics capability and business strategy alignment?. International Journal \\ of Production Economics, 182 113-131.
}




\title{
HOW TO IMPROVE FIRM PERFORMANCE USING BIG DATA ANALYTICS CAPABILITY AND BUSINESS STRATEGY ALIGNMENT?
}

\begin{abstract}
The recent interest in big data has led many companies to develop big data analytics capability (BDAC) in order to enhance firm performance (FPER). However, BDAC pays off for some companies but not for others. It appears that very few have achieved a big impact through big data. To address this challenge, this study proposes a BDAC model drawing on the resource-based theory (RBT) and the entanglement view of sociomaterialism. The findings show BDAC as a hierarchical model, which consists of three primary dimensions (i.e., management, technology, and talent capability) and 11 subdimensions (i.e., planning, investment, coordination, control, connectivity, compatibility, modularity, technology management knowledge, technical knowledge, business knowledge and relational knowledge). The findings from two Delphi studies and 152 online surveys of business analysts in the U.S. confirm entanglement view of the higher-order BDAC model and its impact on FPER. The results also illuminate the significant moderating impact of analytics capability-business strategy alignment on the BDAC - FPER relationship.
\end{abstract}

Keywords: capabilities, entanglement view, big data analytics, hierarchical modelling. 


\section{Introduction}

Firms are increasingly challenged by "Big Data", which has emerged as an exciting frontier of productivity and opportunity in the last few years. Big data analytics capability (BDAC) is widely considered to transform the way in which firms do business (Barton and Court, 2012; Davenport and Harris, 2007a). Recent literature identifies that BDAC has "the potential to transform management theory and practice"(George et al., 2014, p.325), it is the "next big thing in innovation" (Gobble, 2013, p.64); and "the fourth paradigm of science" (Strawn, 2012, p.34); or the next "management revolution" (McAfee and Brynjolfsson, 2012). The incessant growth in worldwide BDAC investment continues as firms search for sustained competitive advantage. These investments to leverage BDAC were around US\$2.1 trillion in 2013 (Lunden, 2013), and are expected to be about US\$3.8 trillion in 2014 (Gartner, 2014).

A recent study by Accenture and General Electric (Columbus, 2014a) reports that, " $87 \%$ of enterprises believe Big Data analytics will redefine the competitive landscape of their industries within the next three years. $89 \%$ believe that companies that do not adopt a Big Data analytics strategy in the next year risk losing market share and momentum". Yet, investment in big data still poses a lot of challenges due to the missing link between analytics capabilities and firm performance. Although analytics have become more mainstream for firms, the steep growth curve of performance using analytics is flattening out (Kiron et al., 2014). Some scholars go so far as to suggest that the investment in BDAC is a myth, which needs to show productivity by reflecting innovative capability and improved firm performance (Manyika et al., 2011). Motivated by this debate, this study aims to examine the role of BDAC in a big data environment. The notion of BDAC, at its core, illuminates the importance of leveraging management, technology and talent capabilities.

Drawing on the resource-based theory (RBT), BDAC is broadly defined as the distinctive capability of firms in setting the optimal price, detecting quality problems, deciding the 
lowest possible level of inventory or, identifying loyal and profitable customers in big data environment (Davenport and Harris, 2007a). This research also views BDAC from the sociomaterialism perspective because it is based on a delicate mixture of management, talent and technology (Kim et al., 2012; Orlikowski and Scott, 2008). Sociomaterialism presents a balanced view by inextricably interlinking and enacting management, technology, and human dimensions because social and material perspectives are inseparable in organization research (Orlikowski, 2007). Thus, based on the sociomaterialism perspective, this research presents an entanglement conceptualization of three BDAC dimensions (i.e., management, technology, and human) that highlights the importance of the complementarities between them for high level operational efficiency and effectiveness for improved performance and sustained competitive advantage.

The existing research largely focuses on anecdotal evidence in proposing the relationship between BDAC and firm performance (FPER) (Agarwal and Dhar, 2014; Mithas et al., 2013). Despite the strong appeal of the concept, empirical evidence about how BDAC contributes to superior FPER is lacking (Abbasi et al., 2016; Davenport et al., 2012). Thus, drawing on the theoretical lenses of the RBT, IT capability and the sociomaterialism perspective, this study addresses the following research questions: "what are the building blocks of BDAC?"; "how is it shaped and strengthened at a firm?"; and "what are its effects on firm performance?" Previous research also highlights the importance of analytics capability-business strategy alignment (ACBSA) in big data environment, which is defined as the extent to which analytics strategies are aligned with the overall business strategy of the organization (Agarwal and Dhar, 2014; McAfee and Brynjolfsson, 2012). Based on the RBT, some scholars propose that internal business processes could be important factors linking BDAC and firm performance (FPER) (Dehning and Richardson, 2002; Melville et al., 2004). As ACBSA is one of the important aspects of internal business processes in the organization's response to 
market changes, (Davenport and Harris, 2007a), this study is motivated to explore the role of ACBSA by answering the research question: "does ACBSA play a moderating role in the relationship between BDAC and FPER?"

To address the research questions, this research develops and validates a BDAC model, and tests the direct effect of BDAC on FPER as well as the moderating effect of ACBSA on BDAC-FPER relationship. The paper proceeds as follows: first, it focuses on the definitions of big data analytics, the conceptual model and hypotheses development. Second, on the method, analysis and findings. Finally, we discuss the theoretical and practical contributions and provide guidelines for future research.

\section{LITERATURE REVIEW}

\subsection{Big Data Analytics Capability}

The concept of 'big data' is generating tremendous attention worldwide. The results of a Google search in mid-August 2014 on the phrases "big data" and "analytics" yielded 822 million and 154 million results, respectively (Agarwal and Dhar, 2014). Owing to the promise of 5-6\% higher productivity and profitability, big data analytics (BDA) has received significant attention on the corporate agenda in recent years. A recent study on Fortune 1000 companies indicates that $91 \%$ of these companies are investing in BDA projects, up from $85 \%$ the year before (Kiron et al., 2014).

According to Kauffman et al. (2012, p.85), the concept of big data is skyrocketing "due to social networking, the internet, mobile telephony and all kinds of new technologies that create and capture data". Indeed, organizations are swimming in the vast sea of data which basically includes transaction data (e.g., structured data from retail transactions, customer profiles); clickstream data (e.g., web and social media content-tweets, blogs, Facebook wall 
postings, etc.); video data (e.g., retail and other stores); and voice data (e.g., data from phone calls, call centers and customer service).

The concept of big data is defined by Goes (2014) as massive amounts of various observational data which support different types of decisions. In their definition of big data, Schroeck et al. (2012) focus more on the greater scope of information which includes realtime information, non-traditional forms of media data, new technology-driven data, the large volume of data, the latest buzz-word, and social media data. Although 'volume' and 'variety' have received much attention in defining big data (e.g., Davenport et al., 2012; IBM, 2012; Johnson, 2012), other studies illuminate the roles of velocity, veracity (e.g., Beulke, 2011; Gentile, 2012; Russom, 2011) and the business value aspects of big data (e.g., Forrester, 2012; IDC, 2012; Oracle, 2012).

Big data analytics capability (BDAC) is broadly defined as the competence to provide business insights using data management, infrastructure (technology) and talent (personnel) capability to transform business into a competitive force (Kiron et al., 2014). The literature also focuses on strategy-led BDAC, that is, analytics that create sustainable value for business (Wixom et al., 2013). For example, Lavalle et al. (2011) identify BDAC as the ability to use big data for decision making, which is essentially connected with the firm's business strategy. Schroeck et al. (2012) focus on "competitive advantages" and "differentiation" while applying big data analytics to analyze real-time data. Kiron et al. (2014) emphasize creating an analytics climate where strategy and capability (e.g., data management, technology and talent) are well aligned in order to achieve competitive advantages. Although BDAC dimensions differ in their terminology, the taxonomy schemes proposed by the literature are similar as they reflect BDA management capability, BDA infrastructure capability and BDA talent capability-related aspects. 


\subsection{Theory}

\subsubsection{Resource based theory (RBT)}

The RBT relies on two core assumptions about firm-based resources to show why some firms perform better than others and how to enhance firm performance. First, even when firms operate within the same industry, they possess a varied mixture of resources (Peteraf and Barney, 2003). This assumption of resource heterogeneity indicates the capability of some firms in accomplishing certain functions with the help of their unique resources. Second, these differences in resources are facilitated by the difficulty of exchanging resources across firms. This assumption indicates resource immobility which highlights the fact that the synergistic benefits from various resources are sustained over time (Barney and Hesterly, 2012). In addition to these two assumptions, the logic of RBT embraces the VRIO framework which clearly states that firm performance depends on the extent to which a firm possesses simultaneously valuable (V), rare (R), imperfectly imitable (I) resources which are properly organized (O) (Amit and Schoemaker, 1993; Barney et al., 2001). First, the valuable dimension of resources enables a firm to enhance net revenues and reduce net costs (Barney and Arikan, 2001), which in other words helps firms capitalize upon an opportunity and minimize a threat (Barney and Hesterly, 2012). Second, the rare dimension indicates that the resources are possessed by a small number of firms to achieve competitive advantages. Third, the imperfectly imitable dimension suggests that firms cannot directly copy or substitute such resources because they are costly to imitate. Research suggests that resource complementarity among resources within a firm make it difficult for competitors to duplicate (Morgan et al., 2009). Resource complementarity occurs when the presence of one resource enables another to leverage firm performance. Finally, the organization dimension focuses on the proper management of valuable, rare and imperfectly imitable resources to leverage their full competitive potential (Barney and Clark, 2007). 
Table 1: Definitions of RBT foundations

\begin{tabular}{|c|c|c|}
\hline RBT foundations & Definitions & Sources \\
\hline Resources & Resources are defined as tangible and intangible assets used by the firms to conceive of and implement its strategies. & Barney and Arikan (2001) \\
\hline Capabilities & $\begin{array}{l}\text { A subset of resources, which represent an "organizationally embedded non-transferable firm-specific resource whose purpose is to improve the } \\
\text { productivity of the other resources possessed by the firm" (p. 389). }\end{array}$ & Makadok (1999) \\
\hline $\begin{array}{l}\text { Resource } \\
\text { complementarity }\end{array}$ & Resources complementary are defined as the extent to which the outcome of one resource is affected by the presence of another. & Morgan et al. (2009) \\
\hline $\begin{array}{l}\text { Resource } \\
\text { heterogeneity }\end{array}$ & $\begin{array}{l}\text { "Strategic resources are distributed unevenly across firms," or "different firms possess different bundles of strategically relevant resources" (p. } \\
\text { 317). }\end{array}$ & Peteraf and Barney (2003) \\
\hline $\begin{array}{l}\text { Resource } \\
\text { immobility }\end{array}$ & Difficulty of trading resources across firms, which allows the benefits of heterogeneous resources to persist over time. & $\begin{array}{l}\text { Barney and Hesterly } \\
\text { (2012) }\end{array}$ \\
\hline $\begin{array}{l}\text { Competitive } \\
\text { advantage }\end{array}$ & Creation of "more economic value than the marginal (breakeven) competitor in its product market" (p. 314). & Peteraf and Barney (2003) \\
\hline $\begin{array}{l}\text { Sustained comp. } \\
\text { advantage (SCA) }\end{array}$ & $\begin{array}{l}\text { A firm has SCA "when it is creating more economic value than the marginal firm in its industry and when other firms are unable to duplicate the } \\
\text { benefits of this strategy" (p. 52). }\end{array}$ & Barney and Clark (2007) \\
\hline VRIO framework & A conceptual framework of RBT (see below) to check various resources and capabilities and their potential to generate competitive advantages. & $\begin{array}{l}\text { Barney and Hesterly } \\
(2012)\end{array}$ \\
\hline Value & $\begin{array}{l}\text { A valuable resource cuts down costs or enhances revenues. For example, studies show that relational resources reduce the cost of serving } \\
\text { customers over time, enhance profit, and increase loyalty. }\end{array}$ & $\begin{array}{l}\text { Reinartz and Kumar } \\
(2003) \text {, Morgan et al. } \\
(2009) \text {, Verhoef et al. } \\
(2001) \text {. }\end{array}$ \\
\hline Rarity & $\begin{array}{l}\text { Since a few firms possess rare resources, the level of ownership varies among firms within an industry with few firms possessing very low and } \\
\text { others are not possessing at all. The logic of passing the test for rarity is basically passing the test for imperfect inimitability. }\end{array}$ & $\begin{array}{l}\text { Makadok (1999), Crook et } \\
\text { al. (2008) }\end{array}$ \\
\hline $\begin{array}{l}\text { Imperfect } \\
\text { inimitability }\end{array}$ & $\begin{array}{l}\text { The long term sustainability of a resource is determined by the extent to which competitors can easily copy it at an acceptable cost. Thus, } \\
\text { imperfect inimitability is a critical assumption which is based on historical conditions (e.g., patents), social complexity (e.g., supply chain } \\
\text { integration management using real time data), and causal ambiguity (e.g., knowledge of data scientists embedded in relational resources). }\end{array}$ & $\begin{array}{l}\text { Makadok (1999), Crook et } \\
\text { al. (2008) }\end{array}$ \\
\hline Organization & $\begin{array}{l}\text { The structure and processes of an organization play an important role in shaping value, rarity and imperfect inimitability of resources in order to } \\
\text { enhance firm performance. This effect of a resource can be experimented by comparing organizational settings with/without a resource. }\end{array}$ & Kozlenkova et al. (2014). \\
\hline
\end{tabular}


Resources and capabilities are the core components of RBT. Whereas 'resources' refers to the tangible and intangible assets (e.g., technology, human \& organizational), 'capabilities' are subsets of the firm's resources which are non-transferable and aim to enhance the productivity of other resources (Makadok, 1999). Capabilities are also identified as tangible or intangible processes that facilitate deployment of other resources and enhance overall productivity. Overall, capabilities represent a special type of resources whose objective is to increase productivity of other resources possessed by the firm (Morgan et al., 2009). According to the RBT, the competency of a firm depends on its capabilities to effectively manage its critical resources (both human and other resources) to achieve firm performance (FPER) (Grant, 2002). An innovative capability always leads toward sustained long-term advantages through its path-dependency, causal ambiguity, and social complexity (Porter and Millar, 1985).

As BDAC is one of the key organizational capabilities identified as the building blocks of competitive advantage in the big data environment (Davenport, 2006), the characteristics of value, rarity, imperfect inimitability, and organization may become a source of superior firm performance (FPER). Peteraf and Barney (2003) defined firm performance as the creation of more economic value than the marginal competitor in its respective industry. Subsequently, Barney and Clark (2007) extended the concept adding "sustainability", when VRIO resources create more economic value than marginal value and the competitors are unable to copy such capabilities and relevant benefits. Although RBT plays a critical role in management research, it has prompted criticisms due to its static and tautological conceptualizations, which have been addressed by definitional and theory refinements (Makadok, 1999; Peteraf and Barney, 2003). Table 1 shows an updated theoretical foundation of RBT for conceptualizing the dimensions of BDAC and predicting firm performance. Our review suggests RBT as a compelling framework for integrating dissimilar BDAC dimensions, their synergistic effects 
on FPER and the contingency of business strategy alignment associated with this overall capabilities-performance relationship. It appears that only a small part of the big data research sheds light on conceptualizing the capability requirements that are key to the performance predictions (Abbasi et al., 2016; Phillips-Wren et al., 2015). Thus we present RBT to argue that firm performance in a data economy is enhanced only when capabilities are valuable, rare, imperfectly imitable and when the firm's organization or management exploits the potential of resources.

\subsubsection{IT capability theories using RBT}

The role of IT capabilities is well established in Information Systems (IS) research, which extends our knowledge about the role of technology in enhancing firm performance. Kim et al. (2012, p.341) defined firm performance as “A firm's competence to change existing business processes better than competitors do in terms of coordination/ integration, cost reduction, and business intelligence/learning”. Drawing on the RBT, the literature in IT capabilities recognizes that competence in leveraging IT-based resources is a source of competitive advantage and differentiates firm performance (Bharadwaj, 2000a; Piccoli and Ives, 2005). Past studies on the relationship between IT capabilities and firm performance using RBT generally report both direct (e.g., Bhatt and Grover, 2005; Powell and DentMicallef, 1997) and indirect (e.g., Pavlou and El Sawy, 2006; Tippins and Sohi, 2003) positive associations (see Table 2). As robust IT capabilities are key dimensions in a big data environment, the level of their applications in various business functions can differentiate firm performance (Davenport, 2006). Thus, scholars increasingly illuminate the role of distinctive IT capability to mobilize and deploy IT-based resources in combination with other organizational resources and capabilities to influence firm performance. 
Table 2: Summary of IT capability studies using RBT

\begin{tabular}{|c|c|c|c|}
\hline Studies on IT capability using RBT & Study type & Types of IT capabilities & $\begin{array}{l}\text { Relationship between IT capability and } \\
\text { business performance }\end{array}$ \\
\hline Kim et al. (2012) & Empirical & $\begin{array}{l}\text { IT management capability, IT infrastructure } \\
\text { capability and IT personnel capability. }\end{array}$ & $\begin{array}{l}\text { Direct relationship with the higher-order IT } \\
\text { capability construct and firm performance. }\end{array}$ \\
\hline Lioukas et al. (2016) & Empirical & Managerial IT capability and alliance performance & Direct \\
\hline Kim et al. (2011) & Empirical & $\begin{array}{l}\text { IT management capabilities, IT personnel } \\
\text { expertise }\end{array}$ & Indirect relationship \\
\hline Bhatt and Grover (2005) & Empirical & $\begin{array}{l}\text { IT infrastructure quality, IT business expertise, IT } \\
\text { relationship infrastructure }\end{array}$ & Direct relationship \\
\hline Pavlou and El Sawy (2006) & Empirical & $\begin{array}{l}\text { IT leveraging competence, dynamic and functional } \\
\text { process capabilities. }\end{array}$ & Indirect relationship \\
\hline Tippins and Sohi (2003) & Empirical & IT competency, organizational learning & Indirect relationship \\
\hline Santhanam and Hartono (2003) & Empirical & IT capability and firm performance & Direct relationship \\
\hline Bharadwaj (2000a) & Empirical & IT capability and firm performance & Direct relationship \\
\hline Powell and Dent-Micallef (1997) & Empirical & $\begin{array}{l}\text { IT human resources, technology resources, } \\
\text { business resources }\end{array}$ & Direct relationship \\
\hline Mata et al. (1995) & Conceptual & IT capability & Direct \\
\hline Ross et al. (1996) & Conceptual & IT capability & Direct \\
\hline
\end{tabular}


Highlighting the role of IT capability on firm performance in big data environment, Davenport et al. (2012) state, “[a]s big data evolves, the architecture will develop into an information ecosystem: a network of internal and external services continuously sharing information, optimizing decisions, communicating results and generating new insights for businesses". The current study's literature review in the big data domain reveals that most studies of BDAC take advantage of the RBT using IT capability dimensions. Thus, Table 2 highlights the current literature on IT capabilities using RBT and the nature of their relationships with firm performance.

\subsubsection{Entanglement view of Sociomaterialism}

In addition to the RBT, the current study's theoretical framework is based on the concept of sociomateriality which refers to the ontological integration of social and material. This viewpoint does not show that the material influences the social (i.e., technological determinism view) or the social influences the material (i.e., social construction view), or a recursive relationship between the social and material (i.e., socio-technical view). Rather, the study embraces the relational ontology of sociomaterialism which posits that the organizational (i.e., BDA management), physical (i.e., IT infrastructure), and human (e.g., analytics skill or knowledge) dimensions are so interwoven that it is difficult to measure their individual contributions in isolation (Orlikowski and Scott, 2008). Orlikowski (2007, p.1437) clarifies that "the social and the material are inextricably related". With this conceptualization, we argue that the BDAC dimensions do not act in isolation; rather, they act together. This view also posits that no properties are native to each constituent dimension because BDAC dimensions are constitutively entangled (Orlikowski, 2007) and mutually supportive (Barton and Court, 2012). Indeed, the individual capability dimension is the manifestation of the overall BDAC building blocks as a whole. The study presents the 
summary of entanglement view of sociomaterialism in Table 3, which indicates that reality does not represent independent objects (social or material), but the joint agency of both.

Table 3: Foundations of entanglement view using sociomaterialism

\begin{tabular}{|l|l|}
\hline Foundations of Entanglement view & $\begin{array}{l}\text { Definitions using sociomateriality (Latour, 2005; Orlikowski, } \\
\text { 2007; Orlikowski and Scott, 2008; Stein et al., 2014) }\end{array}$ \\
\hline Ontology & $\begin{array}{l}\text { Human and non-human are inextricably entangled to work } \\
\text { together. }\end{array}$ \\
\hline Epistemology & $\begin{array}{l}\text { Focus on heterogeneous networks and their insights rather than } \\
\text { individuals or artefacts. }\end{array}$ \\
\hline Sociomateriality & There is no separable social or materiality, all are interlinked. \\
\hline humamics of humants and non- & $\begin{array}{l}\text { The inherent inseparability between social and material agencies } \\
\text { are treated the same for analytical purposes. The relationship is } \\
\text { emergent and shifting because the boundary of relation is not } \\
\text { fixed. }\end{array}$ \\
\hline What the perspective emphasizes & $\begin{array}{l}\text { Focuses on the inseparable relationship between human and } \\
\text { material agencies. } \\
\text { Materiality is integral to human activities } \\
\text { Illuminates how organizational capabilities are sociomaterial. } \\
\text { Demonstrates the organization of capabilities at a macro (i.e., } \\
\text { overall capability) or micro level (i.e., technical, human and } \\
\text { management) } \\
\text { Overall, it highlights the performativity of practices. }\end{array}$ \\
\hline Unit of analysis & $\begin{array}{l}\text { Sociomaterial practice, such as BDAC is an emergent } \\
\text { characteristic of sociomaterial activities. It indicates that } \\
\text { boundaries between social (e.g., personnel, managerial) and } \\
\text { material (e.g., technology) dimensions are not fixed but enacted } \\
\text { in practice. }\end{array}$ \\
\hline
\end{tabular}

In a similar spirit, Kallinikos (2007) explores information growth and states that data, information and knowledge are entangled, and that hierarchical organizational resources could be leveraged through their synergistic ties. This view is consistent with the prior literature on the RBT which believes in achieving sustained competitive advantage by accumulating heterogeneous resources (Barney, 1991; Peteraf, 1993) in an organization through complementarity and co-specialization (Powell and Dent-Micallef, 1997). Whereas 
complementarity is defined as being when the value of one resource is enhanced by the presence of other resources (Powell and Dent-Micallef, 1997), co-specialization is defined as being when one resource has little or no value without another (Clemons and Row, 1991). Overall, the current study proposes utilization of entanglement conceptualization which highlights the fact that BDAC dimensions have both complementary and co-specialization attributes, which act together in a synergistic fashion to influence firm performance (FPER). To the best of our knowledge, in the big data literature, there is a paucity of research which has explored and encapsulated BDAC dimensions by applying the entanglement view under sociomaterialism.

\subsection{Typologies of BDAC}

The literature in big data identifies three key building blocks of BDAC as follows: organizational (i.e., BDA management), physical (i.e., IT infrastructure), and human (e.g., analytics skill or knowledge). For example, Davenport et al. (2012) suggest that the focus should be on: (a) big data management capability across core business and operations functions; (b) data scientists in terms of human resource capability; and (c) advanced IT infrastructure capability (e.g., open-source platforms, such as Apache Hadoop, and cloudbased computing). McAfee and Brynjolfsson (2012) identify the critical challenges of BDAC as being talent management, IT infrastructure, and decision-making capability across different functions. In a similar spirit, Barton and Court (2012) highlight the following three dimensions of capability: big data management ability to predict and optimize models; IT infrastructure to manage multiple data sources; and the expertise of front line employees in understanding the tools. Also, Kiron et al. (2014), when considering the key dimensions of BDAC, focus on management culture, data management infrastructure, and skills. In another recent study, Wixom et al. (2013) recognize BDA capabilities in terms of strategy, data and people to conceptualize BDAC dimensions. According to Phillips-Wren et al. (2015, p.450) 
"Big data adds new dimensions to analytics. It offers enhanced opportunities for insight but also requires new human and technical resources due to its unique characteristics". Therefore, one notable observation is that few scholars disagree with the inclusion of BDA management capability, BDA infrastructure capability, and BDA talent capability as key dimensions of BDAC. Table 4 summarizes the typologies of BDAC that have been explored in recent big data literature. 
Table 4: Typologies of Big Data Analytics Capabilities

\begin{tabular}{|c|c|c|c|}
\hline \multirow{2}{*}{$\begin{array}{l}\text { Related } \\
\text { studies }\end{array}$} & \multicolumn{3}{|c|}{ Typologies } \\
\hline & BDA management capability & BDA technology capability & BDA talent capability \\
\hline $\begin{array}{l}\text { Kiron et al. } \\
(2014)\end{array}$ & $\begin{array}{l}\text { Analytics planning, sharing and } \\
\text { coordination, investment, control on } \\
\text { analytics as a whole. }\end{array}$ & $\begin{array}{l}\text { Organizational openness, compatibility } \\
\text { analytics technology, collaborative use of } \\
\text { data (connectivity). }\end{array}$ & $\begin{array}{l}\text { Analytical talent, technical and business } \\
\text { knowledge, organization as a whole effective } \\
\text { in disseminating insights. }\end{array}$ \\
\hline $\begin{array}{l}\text { Davenport et } \\
\text { al. (2012) }\end{array}$ & $\begin{array}{l}\text { Analytics management at core business } \\
\text { and operational functions. }\end{array}$ & $\begin{array}{l}\text { Open source platforms (e.g., Apache } \\
\text { Hadoop, and cloud-based computing) } \\
\text { ensuring connectivity, compatibility and } \\
\text { modularity. }\end{array}$ & Data scientists or human resource capability \\
\hline $\begin{array}{l}\text { McAfee and } \\
\text { Brynjolfsson } \\
(2012)\end{array}$ & Corporate strategy & IT infrastructure & Skills and knowledge of data scientists \\
\hline $\begin{array}{l}\text { Wixom et al. } \\
\text { (2013) }\end{array}$ & $\begin{array}{l}\text { Strategy (e.g., cost, service, price, } \\
\text { productivity) }\end{array}$ & Data (e.g., data model, standard and control) & $\begin{array}{l}\text { People (e.g., capability to use basic reporting } \\
\text { and ad-hoc query tools, performance } \\
\text { management dashboard applications, } \\
\text { customer facing web portal applications etc. ) }\end{array}$ \\
\hline $\begin{array}{l}\text { Barton and } \\
\text { Court (2012) }\end{array}$ & $\begin{array}{l}\text { Management (ensuring data and models } \\
\text { work together). }\end{array}$ & $\begin{array}{l}\text { Data (volume, variety, veracity etc.) and IT } \\
\text { platform. }\end{array}$ & $\begin{array}{l}\text { Talent (e.g., capability to build advanced } \\
\text { analytics models for predicting and } \\
\text { optimizing outcomes). }\end{array}$ \\
\hline $\begin{array}{l}\text { Wamba et al. } \\
(2015)\end{array}$ & $\begin{array}{l}\text { Management (planning, investment and } \\
\text { control) }\end{array}$ & $\begin{array}{l}\text { Infrastructure (connectivity, compatibility, } \\
\text { modularity) }\end{array}$ & $\begin{array}{l}\text { Talent (management, technical, business } \\
\text { relational etc.) }\end{array}$ \\
\hline $\begin{array}{l}\text { Ransbotham } \\
\text { et al. (2015) }\end{array}$ & $\begin{array}{l}\text { Management (planning options, } \\
\text { coordination between analytical } \\
\text { producers and managers, model based } \\
\text { decisions and control) }\end{array}$ & $\begin{array}{l}\text { Infrastructure and processes (machine } \\
\text { learning, data management and information } \\
\text { systems) to improve data quality. }\end{array}$ & $\begin{array}{l}\text { Talent (e.g., domain knowledge, statistics } \\
\text { and other technical skills). }\end{array}$ \\
\hline
\end{tabular}




\section{RESEARCH MODEL AND HYPOTHESES}

In order to develop a research model to measure BDAC, this study began by investigating commonly cited dimensions that influence BDAC perception in big data environment (Alismaili et al., 2016). The review identified three primary dimensions that reflect BDAC, that is, BDA management capability, BDA technology capability and BDA talent capability (see Table 1). Throughout our review and theoretical exploration, BDAC was frequently identified as a higher-order and multidimensional construct, which indicated that several subdimensions would determine the initially identified primary dimensions. As such, we conducted two Delphi studies to explore the subdimensions of BDAC under each primary dimension identified in the review. Round one of the Delphi study was conducted in November $2014(n=51)$ and round two in February $2015(n=43)$ with respondents that represent balance of analytics practitioners, consultants and academics. Using these two studies, we found support for 11 subdimensions (i.e., BDA planning, investment, coordination, control, connectivity, compatibility, modularity, technical knowledge, technology management knowledge, business knowledge, and relational knowledge) under three primary dimensions (i.e., management capability, infrastructure capability and talent capability) proposed in the research model (see Fig. 1). Drawing on the RBT and entanglement view, the research model conceptualizes BDAC dimensions as having the attributes of complementarity and co-specialization, which work together in a synergistic fashion to achieve distinctive firm performance (Clemons and Row, 1991; Kim et al., 2012; Powell and Dent-Micallef, 1997; Tippins and Sohi, 2003). To evaluate how RBT unifies entanglement view of sociomaterialism to support our BDAC model, we review each theory's complementarities in Table 5. 
Table 5: RBT and Entanglement view of Sociomaterialism: Similarities \& Complementarities to support the BDAC model

\begin{tabular}{|c|c|c|c|}
\hline Theory & Key ideas & Similarities with the BDAC model & Complements to the BDAC model \\
\hline $\begin{array}{l}\text { Resource based theory } \\
\text { (Barney, 1991) }\end{array}$ & $\begin{array}{l}\text { Resources are valuable, rare, imperfectly } \\
\text { inimitable and supported by } \\
\text { organizational structure and processes to } \\
\text { enhance firm performance. }\end{array}$ & $\begin{array}{l}\text { Similar to RBT, BDAC relies on } \\
\text { the assumptions of resource } \\
\text { heterogeneity, imperfectly mobile } \\
\text { and inimitable resources and } \\
\text { recognize the importance of } \\
\text { strategic alignment to leverage the } \\
\text { resources to influence superior } \\
\text { firm performance. }\end{array}$ & $\begin{array}{l}\text { Provides an explanation of how } \\
\text { big data organizations enhance } \\
\text { firm performance because, first, } \\
\text { they have the required } \\
\text { capabilities; second, they } \\
\text { successfully align analytics } \\
\text { capabilities-firm strategies; }\end{array}$ \\
\hline $\begin{array}{l}\text { Entanglement view using } \\
\text { sociomaterialism (Latour, } \\
\text { 2005; Orlikowski, 2007; } \\
\text { Orlikowski and Scott, } \\
\text { 2008; Stein et al., 2014) }\end{array}$ & $\begin{array}{l}\text { The relationship between human and } \\
\text { material agencies is inseparable and } \\
\text { inextricably interlinked. }\end{array}$ & $\begin{array}{l}\text { The proposed BDAC model relies } \\
\text { on the building blocks of } \\
\text { hierarchical capabilities (i.e., } \\
\text { management, technology and } \\
\text { talent). Similar to entanglement } \\
\text { view, all the dimensions of BDAC } \\
\text { are interlinked and mutually } \\
\text { supportive. }\end{array}$ & $\begin{array}{l}\text { Provides the logic of how people, } \\
\text { systems, data and management are } \\
\text { entangled to influence firm } \\
\text { performance. The hierarchical } \\
\text { BDA capabilities are leveraged } \\
\text { through their synergistic ties } \\
\text { which are based on } \\
\text { complementarity and co- } \\
\text { specialization. }\end{array}$ \\
\hline
\end{tabular}


Although BDAC dimensions are distinct, they are interwoven to mutually support and reinforce each other in the big data environment to realize business goals. Thus, the study presents an integrated approach to BDAC and their alignment with business strategies for enhancing firm performance. Towards the development of an integrated BDAC, we identified subdimensions under each primary dimension based on the themes identified in the Delphi studies. At this stage, we consulted the literature in the following sections to support our Delphi findings.

\subsection{BDA management capability (BDAMAC)}

BDAMAC is an important aspect of BDAC ensuring that solid business decisions are made applying proper management framework. Four core themes were found to constitute perceptions of BDAMAC; these were termed as BDA planning, investment, coordination, and control. The BDAMAC starts with the proper BDA planning process which identifies business opportunities and determines how the big data-based models can improve firm performance (FPER) (Barton and Court, 2012). For example, Amazon planned to engage a type of predictive modelling technique called 'collaborative filtering' using customer data to generate 'you might also want' prompts for each product bought or visited. Amazon revealed at one point that $30 \%$ of sales were generated through its recommendation engine (Manyika et al., 2011). Similarly, BDA investment decisions are critical aspects of BDAMAC as they reflect cost-benefit analyses. For example, Netflix Inc. transformed its BDAC by investing in web data of over one billion movie reviews in categories such as liked, loved, hated, etc. to recommend movies that optimize the ability to meet customer preferences (Davenport and Harris, 2007b). According to Ramaswamy (2013), “[w]e found that companies with huge investments in Big Data are generating excess returns and gaining competitive advantages, putting companies without significant investments in Big Data at risk". Thus, it is important to manage this capability in order to enhance revenue-generating activities, as have been applied by 
Netflix, General Electric, and LinkedIn, to drive growth. In addition, BDA coordination receives increased attention in the big data environment, representing a form of routine capability that structures the cross-functional synchronization of analytics activities across the firm (Kiron et al., 2014). For example, analysts of Procter \& Gamble work in coordination across operations, the supply chain, sales, consumer research, and marketing to improve total business performance (Davenport, 2006). Finally, BDA controlling functions are performed by ensuring proper commitment and utilization of resources, including budgets and human resources. For example, the controlling functions in Amazon represent an evaluation of BDA proposals with reference to BDA plans, clarification of the responsibilities of the BDA unit, development of performance criteria for BDA, and continuous performance monitoring of the BDA unit (Schroeck et al., 2012).

\subsection{BDA technology capability (BDATEC)}

BDATEC refers to the flexibility of the BDA platform (e.g., connectivity of cross-functional data, compatibility of multiple platforms, modularity in model building, etc.) in relation to enabling data scientists to quickly develop, deploy, and support a firm's resources. Three core themes underpin perceptions of BDATEC: connectivity, compatibility and modularity. It is important to tackle volatile business conditions (e.g., changes in competition, market dynamics, or consumer behaviour) and align resources with long-term and short-term business strategies (e.g., new product development, diversification, etc.). With a flexible BDATEC, firms can source and connect various data points from remote, branch, and mobile offices; create compatible data-sharing channels across various functions; and develop models and applications to address changing needs. Thus, the flexibility of a firm's BDAC depends on two components: the first component is connectivity among different business units in sourcing and analyzing a variety of data from different functions (e.g., supply chain management, customer relationship management, etc.). For 
example, banks in the big data environment often improve customer service operations by combining data from automated teller machine (ATM) transactions, online queries, social media comments, and customer complaints (Barton and Court, 2012). The second component, compatibility, enables continuous flows of information for real-time decisions. It also helps clean-up operations to synchronize and merge overlapping data and to fix missing information. For example, Amazon embraces compatibility in the BDAC platform by using cloud technologies which help in collaboration, experimentation, and rapid analysis (Davenport and Harris, 2007a). Modularity embodies flexible platform development which allows the addition, modification or removal of features to, or from, the model as needed. It helps in tapping business opportunities and improving FPER.

\subsection{BDA talent capability (BDATLC)}

BDATLC refers to the ability of an analytics professional (e.g., someone with analytics skills or knowledge) to perform assigned tasks in the big data environment. This 'know-how' and other types of knowledge are referred to as capabilities in this context, and can create or sustain competitive advantage (Constantiou and Kallinikos, 2014). Based on the findings of Delphi studies and the literature, the study proposes that analysts should be competent in four distinct but equally important skill sets: technical knowledge (e.g., database management); technology management knowledge (e.g., visualization tools, and techniques management and deployment); business knowledge (e.g., understanding of short-term and long-term goals); and relational knowledge (e.g., cross-functional collaboration using information). Firstly, technical knowledge refers to knowledge about technical elements, including operational systems, statistics, programming languages, and database management systems. For example, data scientists at Yahoo developed Apache Hadoop and at Facebook created the Hive language for Apache Hadoop 
projects - the path has been followed by other data-driven companies, such as Google, Amazon, Walmart, eBay, LinkedIn and Twitter, to transform their big data analytics capability (BDAC) (Davenport and Patil, 2012). Secondly, technology management knowledge refers to the big data resource management knowledge that is necessary to support business goals. For example, analytics professionals at Netflix use a visualization and demand analytics tool to understand consumer behavior and preferences: this has led them to achieve success in their "House of Cards" program in the United States (USA) (Ramaswamy, 2013). Thirdly, business knowledge refers to the understanding of various business functions and the business environment. For example, analytics professionals at Intuit are nurtured to develop their feel for business issues and empathy for customers. Finally, relational knowledge refers to the ability of analytics professionals to communicate and work with people from other business functions. Data scientists need close relationships with the rest of the business: this has been instrumental in LinkedIn in developing its new feature, 'people you may know', and achieving a 30\% higher click-through rate. Overall, balanced proficiency needs to be developed through ongoing training and coaching in managing the project, the infrastructure and knowledge (Barton and Court, 2012).

Overall, the study presents a hierarchical BDAC model (Figure 1) drawing on the findings of Delphi studies, the literature in RBT (Grant, 1991), IT capability (Kim et al., 2012), entanglement view of sociomaterialism (Orlikowski, 2007; Orlikowski and Scott, 2008) and the seminal studies in big data (Barton and Court, 2012; Davenport et al., 2012; Davenport and Harris, 2007a; Kiron et al., 2014; McAfee and Brynjolfsson, 2012). 


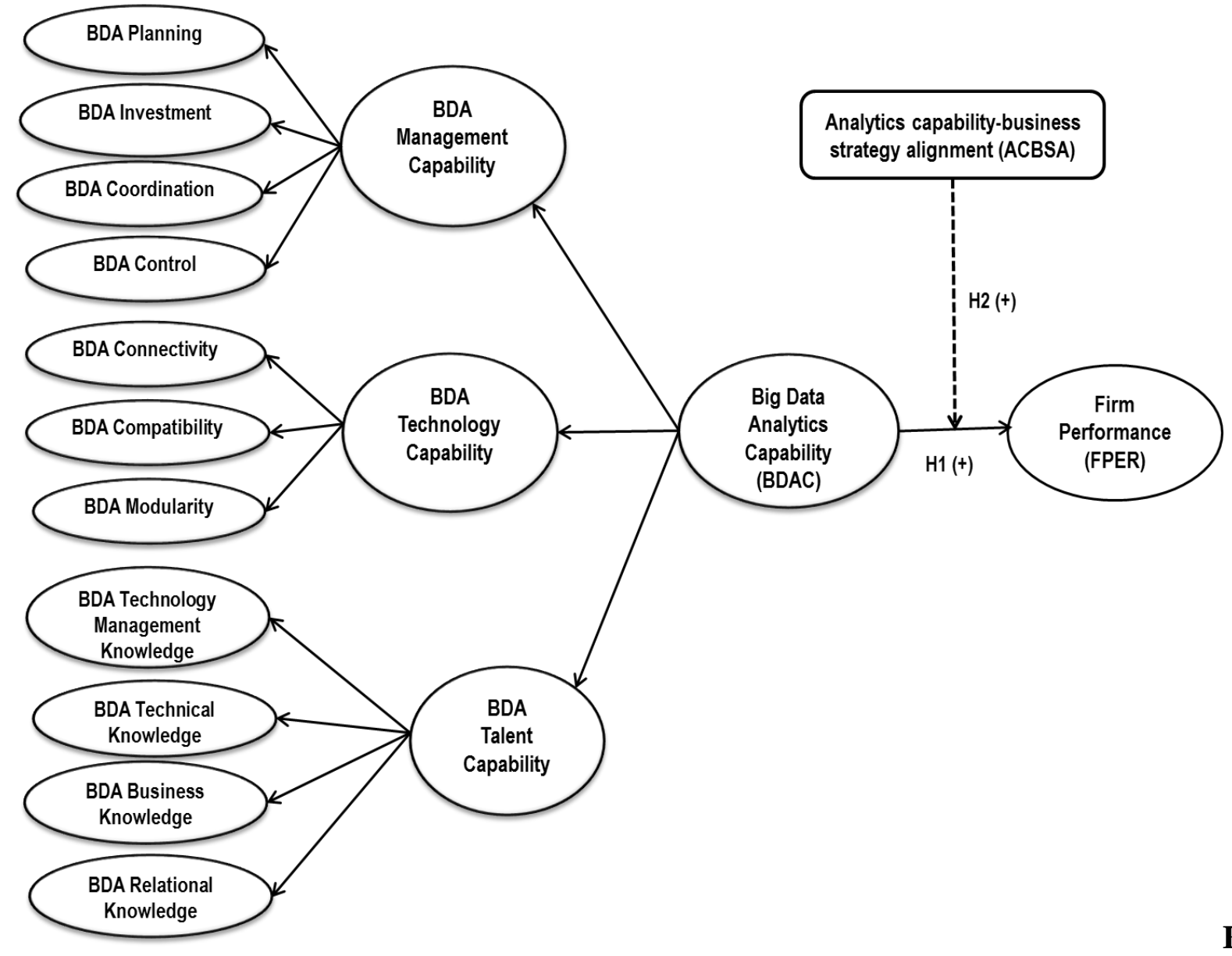

Figure 1: Research Model 


\subsection{Big Data Analytics Capability and Firm Performance}

Big data analytics capability (BDAC) is widely acknowledged to play a vital role in increasing business and firm performance (FPER) (Wixom et al., 2013). The literature provides evidence of a relationship between BDAC and FPER in, for instance: price optimization and profit maximization (Davenport and Harris, 2007a; Schroeck et al., 2012); sales, profitability, and market share (Manyika et al., 2011); and return on investment (ROA) (Barton and Court, 2012; Columbus, 2014a; McAfee and Brynjolfsson, 2012; Ramaswamy, 2013). Srinivasan and Arunasalam (2013) show that BDAC can benefit firms in healthcare by reducing cost (i.e., reduced amount of waste and fraud) and improving the quality of care (i.e., safety and efficacy of treatment). Wixom et al. (2013) show that BDAC can improve FPER by improving productivity both in tangible (i.e., less paper reporting) and intangible (company reputation) benefits. Thus, a firm that creates superior BDAC should be able to maximize FPER by facilitating the pervasive use of insights gained from its BDAC. Drawing on the RBT (Barney, 1991; Grant, 1991) and the relational ontology of sociomaterialism (Kim et al., 2012; Orlikowski, 2007; Orlikowski and Scott, 2008), we argue that superior FPER in the big data environment emerges from unique combinations of organizational (i.e., BDA management), physical (i.e., IT infrastructure), and human (e.g., analytics skill or knowledge) resources that are constitutively entangled, valuable and difficult to imitate (Barton and Court, 2012). Since IT is acknowledged as a critical component of BDAC, drawing on the IT capability literature, we argue that competence in mobilizing and deploying various BDAC resources differentiates firm performance (FPER) and creates competitive advantage (Piccoli and Ives, 2005). Following this reasoning, we propose the following hypothesis: 


\section{H1: Big data analytics capability (BDAC) will have a positive impact on firm performance (FPER).}

\subsection{Analytics Capability, Business Strategy Alignment and Firm Performance}

Strategy receives an increasing amount of attention in the big data environment because business opportunities and other sources of macro (e.g., economic trends) and micro (e.g., customer preferences) environmental change can easily be identified in this context (Constantiou and Kallinikos, 2014; George et al., 2014). Analytics capability and business strategy alignment (ACBSA) have received much attention from both academics and practitioners. According to Davenport et al. (2012, p.46), “[a] key tenet of big data is that the world and the data that describe it are constantly changing, and organizations that can recognize the changes and react quickly and intelligently will have the upper hand". Due to the unpredictable nature of big data, strategy researchers have always emphasized establishing the strategic fit or alignment, viewing the firm as a collection of resources, interlinked by a specific governance structure (Peteraf, 1993). ACBSA is defined as the extent to which BDAC is aligned with the overall strategy of the organization. Alignment between BDAC and business strategy depends on visionary leadership which helps to synchronize capability with the functional goals and objectives, including marketing and operations management. For example, McAfee and Brynjolfsson (2012, p.66) state that "companies succeed in the big data era not simply because they have more or better data, but because they have leadership teams that set clear goals, define what success looks like, and ask the right questions. Big data's power does not erase the need for vision or human insight". A larger amount of synchronization between BDAC and business strategies increases the synergy among different functional units and positively impacts FPER. As a result of greater synchronization in the big data environment, it is possible to leverage BDAC by overcoming cognitive, structural and political challenges. 
However, even though alignment has received increased attention in the BDA literature (Davenport, 2006; McAfee and Brynjolfsson, 2012), not enough is known about the impact of ACBSA on BDAC-FPER relationship. Illuminating the importance of ACBSA, Barton and Court (2012) state that, “[m]any companies grapple with such problems, often because of a mismatch between the organization’s existing culture and capabilities and the emerging tactics to exploit analytics successfully. In short, the new approaches don't align with how companies actually arrive at decisions, or they fail to provide a clear blueprint for realizing business goals". Therefore, ACBSA is a distinctive capability which allows firms to link overall capability with firm performance. This capability is firmly incorporated in the organizational routines of leading big data corporations including Amazon, Dell, Netflix, and Tesco, thus making it harder for competitors to copy.

ACBSA also has the characteristics of a strategic organizational capability that can help firms match resources with changing market opportunities. In addition, it helps to align resources with market dynamics aided by multidimensional capability. The main way through which BDAC can help organizations achieve FPER is by aligning capability with the strategic plan. Big data analytics capability (BDAC) can influence organizational performance through the moderating role of alignment. As ACBSA is a strategic capability, it depends on a firm's ability to implement and leverage other capability resources (Bharadwaj, 2000b). This argument indicates that ACBSA influences the relationship between BDAC and FPER. A high level of organizational (i.e., BDA management), physical (i.e., IT infrastructure), and human (e.g., analytics skill or knowledge) resources could enable firms to align their business strategies to achieve high sales growth, market share growth, profitability, and return on investment (ROI). In the absence of business strategy alignment with BDAC, there is every possibility of the firm's performance declining. Thus, we posit that ACBSA will serve as a moderator of the relationship between BDAC and FPER: 
H2: Analytics capability-business strategy alignment (ACBSA) will moderate the relationship between big data analytics capability (BDAC) and firm performance (FPER).

\section{Research Methodology}

\subsection{Scale Development}

For this study, all measurement items were taken from the existing literature and were adapted to fit the big data analytics context (Appendix 1). Scales were customized to fit the context of our study to ensure that they were applicable to the analytics managers. Subsequently, eight experienced analytics academics conducted the content validity of the survey. A pilot study of the survey was then conducted with a total of 61 respondents enrolled from various big data analytics groups on LinkedIn. This allowed our proposed model to be tested for robustness before the final data collection. All our items were measured using a 7-point Likert scale. We controlled for the demographic variables relevant to the analytics managers such as, age, gender, education, experience, industry and the size of organization to avoid any bias due to demographics.

\subsection{Data Collection}

The data collection of the main survey for this study was undertaken by a leading market research firm in the USA. The data collection was conducted in April, 2014. To be more precise, an invitation to participate in the study was sent on to a random sample of 826 people who were using big data in the USA and who were members of the 'business analysts', 'big data analytics', and 'IT professionals' groups. A total of 668 panel members agreed to participate in the study. After a careful analysis of all responses, 152 valid questionnaires were considered to have been correctly filled out and appropriate for further analysis, thus giving a response rate of $37.72 \%$. 
Table 6 shows that of the respondents, $34.2 \%$ are aged 50+ while $26.3 \%$ are aged between 34 and 41 years old, while respondents aged between 42 and 49 years old and between 26 and 33 years old represent 19.7\% and 15.1\%, respectively. It is clear that our sample is dominated by people more than 34 years old (about $80.2 \%$ of the sample). With regard to gender, $70.4 \%$ are respondents are men while $29.6 \%$ are women. In terms of level of education, the data analysis shows that $27 \%$ of respondents hold a postgraduate degree (Master's/PhD), followed by $40.1 \%$ with an undergraduate degree, $23.7 \%$ with a college qualification degree, $6.6 \%$ with secondary qualifications, $1.3 \%$ with primary qualifications, and $1.3 \%$ without a formal qualification. In terms of the number of years working with their firm, a breakdown of respondents shows that $33.6 \%$ have spent from 2-5 years with their firm, followed by $22.4 \%$ with time spent from 6-10 years with their firm. Based on the data analysis, $22.4 \%$ of respondents work in information and communication, $21.7 \%$ work in financial and insurance activities, while $13.8 \%$ work in other service activities. With regard to their firm's number of employees, $19.7 \%$ of respondents claimed to be in a firm with 100,000 employees or more. Overall $57.2 \%$ of the respondents are in firms with 5,000 employees or more.

Table 6: Demographic Profile of Respondents

\begin{tabular}{|l|c|c|}
\hline Variable & Frequency & Percentage \\
\hline Age & & \\
\hline $18-25$ & 7 & 4.6 \\
\hline $26-33$ & 23 & 15.1 \\
\hline $34-41$ & 40 & 26.3 \\
\hline $42-49$ & 30 & 19.7 \\
\hline $50+$ & 52 & 34.2 \\
\hline Gender & & \\
\hline Male & 107 & 70.4 \\
\hline Female & 45 & 29.6 \\
\hline Education & & \\
\hline No formal qualification & 2 & 1.3 \\
\hline Primary qualifications & 2 & 1.3 \\
\hline
\end{tabular}




\begin{tabular}{|c|c|c|}
\hline Secondary qualifications & 10 & 6.6 \\
\hline College qualification (diploma/certificate) & 36 & 23.7 \\
\hline Undergraduate degree & 61 & 40.1 \\
\hline Postgraduate degree (Master's/PhD) & 41 & 27 \\
\hline \multicolumn{3}{|l|}{ Experience } \\
\hline Less than one year & 11 & 7.2 \\
\hline $2-5$ years & 51 & 33.6 \\
\hline $6-10$ years & 34 & 22.4 \\
\hline $11-15$ years & 27 & 17.8 \\
\hline $16-20$ years & 17 & 11.2 \\
\hline Over 20 years & 12 & 7.9 \\
\hline \multicolumn{3}{|l|}{ Industry } \\
\hline Administrative and support service activities & 1 & 0.7 \\
\hline Agriculture, forestry, and fishing & 2 & 1.3 \\
\hline Arts, entertainment, and recreation & 1 & 0.7 \\
\hline Education & 11 & 7.2 \\
\hline Electricity, gas, steam, and air conditioning supply & 1 & 0.7 \\
\hline Financial and insurance activities & 33 & 21.7 \\
\hline Human health and social work activities & 9 & 5.9 \\
\hline Information and communication & 34 & 22.4 \\
\hline Manufacturing & 16 & 10.5 \\
\hline Professional, scientific, and technical activities & 10 & 6.6 \\
\hline Public administration and defense; compulsory social security & 1 & 0.7 \\
\hline Real estate activities & 2 & 1.3 \\
\hline Transportation and storage & 3 & 2 \\
\hline Water supply; sewerage; waste management & 1 & 0.7 \\
\hline Wholesale and retail trade; repair of motor vehicles and motorcycles & 6 & 3.9 \\
\hline Other service activities & 21 & 13.8 \\
\hline \multicolumn{3}{|l|}{ Number of employees in firm (Firm Size) } \\
\hline $0-19$ & 1 & 0.7 \\
\hline $20-99$ & 7 & 4.6 \\
\hline $100-249$ & 7 & 4.6 \\
\hline $250-499$ & 13 & 8.6 \\
\hline $500-999$ & 8 & 5.3 \\
\hline $1,000-2,499$ & 14 & 9.2 \\
\hline $2,500-4,999$ & 15 & 9.9 \\
\hline $5,000-9,999$ & 13 & 8.6 \\
\hline
\end{tabular}




\begin{tabular}{|l|c|c|}
\hline $10,000-24,999$ & 18 & 11.8 \\
\hline $25,000-49,999$ & 12 & 7.9 \\
\hline $50,000-99,999$ & 14 & 9.2 \\
\hline $100,000+$ & 30 & 19.7 \\
\hline
\end{tabular}

\section{Analysis and Findings}

The study applies the repeated indicator approach (see Table 7) to estimate all the constructs simultaneously instead of separate estimates of lower-order and higher-order dimensions. The study specifies that the mode of measurement is reflective as the first-order dimensions are reflective (Mode A) of the higher-order dimensions (Chin, 2010; Ringle et al., 2012). Furthermore, the model is reflective because the theoretical direction of causality is from constructs to items. Specifically, the measures used in the study are manifestations of constructs, that is, changes in the constructs cause changes in the measures $(L V s \rightarrow M V s)$.

The study estimates the model using partial least squares (PLS) path modeling which is able to ensure more theoretical parsimony and less model complexity (Wetzels et al., 2009). To be specific, the study applies PLS because this approach is consistent with the objective of the study, which aims to develop and test a theoretical model through explanation and prediction. Indeed, PLS is more suitable for estimating a hierarchical model than covariance-based SEM (CBSEM) because PLS can successfully avert the constraints on distributional properties (multivariate normality), measurement level, sample size, model complexity, model identification and factor indeterminacy (Hair et al., 2011). SmartPLS 3.0 (Ringle et al., 2014) was used to estimate the model with a path weighting scheme for the inside approximation. The study applied nonparametric 
bootstrapping (Chin, 1998a; Efron and Tibshirani, 1993; Tenenhaus et al., 2005) with 5,000 replications to obtain the standard errors of the estimates (Hair Jr et al., 2013). As per the guidelines of hierarchical modeling (Becker et al., 2010; Chin, 2010), an equal number of indicators were repeatedly used to estimate the scores of first-order constructs and second-order constructs. In this way, the study created the third-order BDAC construct that represents all the indicators of the underlying first-order latent variables (LVs).

Table 7: Equations for Hierarchical Modeling using Partial Least Squares (PLS)

\begin{tabular}{|c|c|c|}
\hline First-order BDAC model & Second-order BDAC model & Third-order BDAC model \\
\hline $\begin{array}{c}y_{i}=\Lambda_{y} . \eta_{j}+\varepsilon_{i} \\
y_{i}=\begin{array}{c}\text { manifest variables (e.g., items } \\
\text { of BDA planning) }\end{array} \\
\Lambda_{y}=\text { loadings of first-order LVs } \\
\eta_{j}=\text { first-order LVs (e.g., BDA } \\
\text { planning) } \\
\varepsilon_{i}=\text { measurement error }\end{array}$ & $\begin{array}{c}\eta_{j}=\Gamma \cdot \xi_{k}+\zeta_{j} \\
\eta_{j}=\text { first-order factors (e.g., } B D A \\
\text { planning) } \\
\Gamma=\text { loadings of second-order LVs } \\
\xi_{k}=\text { second-order LVs (e.g., } B D A \\
\text { management capability) } \\
\zeta_{j}=\text { error of first-order factors }\end{array}$ & $\begin{array}{c}\eta_{j}=\beta . \eta_{j}+\Gamma . \xi_{k}+\zeta_{j} \\
\eta_{j}=\text { second-order factors (i.e., } \\
\text { management, technology and talent } \\
\text { capability) } \\
\beta \eta_{j}=\text { higher-order LVs with } \\
\text { loadings (i.e., from first to the } n^{\text {th }} \\
\text { order, except the highest order) } \\
\Gamma \xi_{k}=\text { the highest-order LV with } \\
\text { loadings (i.e., third-order BDAC } \\
\text { construct) } \\
\zeta_{j}=\text { error of second-order factors }\end{array}$ \\
\hline
\end{tabular}




\subsection{Measurement Model}

Confirmatory factor analysis (CFA) was used to verify the convergent and discriminant validity of the first-order measurement model (Table 8).

The 11 constructs that make up this first-order model are: BDA planning, investment, coordination, control, connectivity, compatibility, modularity, technical knowledge, technology management knowledge, business knowledge, and relational knowledge. Initially, the study calculated all the item loadings which exceeded the cut-off values of 0.7 and were significant at $\mathrm{p}<0.001$. The higher average of the item loadings $(>0.80)$ and a narrower range of difference provide strong evidence that respective items have greater convergence in measuring the underlying construct (Chin, 2010). The study also calculated average variance extracted (AVE) and composite reliability (CR) (Chin, 1998a; Fornell and Larcker, 1981) to confirm the reliability of all the measurement scales. Average variance extracted (AVE) measures the amount of variance that a construct captures from its indicators relative to measurement error, whereas CR measures internal consistency (Chin, 2010). Basically, these two tests indicate the extent of association between a construct and its indicators. Composite reliability (CR) and AVE of all scales are either equal to or exceed 0.80 and 0.50 cut-off values, respectively (Fornell and Larcker, 1981; Hair et al., 2013). Here, the lowest AVE is 0.600 for BDA technology and the lowest CR is 0.902 for BDA connectivity: all of these values exceed the recommended thresholds. Thus, the study confirmed that all the item loadings and values for CR and AVE exceed their respective cut-off values, thus ensuring adequate reliability and convergent validity(Fornell and Larcker, 1981). Furthermore, for formative control variables, the study found that the factor weights of age, gender, education, experience, industry and firm size are significant at $\mathrm{p}<0.01$. The test of collinearity is satisfactory for the 
formative variables as the variance inflation factor (VIF) ranges between 1.016 to 1.214 , much less than the cut-off value of 5. Overall, the measurement model provides evidence of adequate reliability and validity in terms of both the reflective and formative constructs.

As shown in Table 9, the study calculated the square root of the AVE in the diagonals of the correlation matrix. As these values exceed the intercorrelations of the construct with the other constructs in the first-order model, discriminant validity is confirmed (Chin, 1998b, 2010; Fornell and Larcker, 1981). This test indicates that the constructs do not share the same type of items and they are conceptually distinct from each other (Chin, 2010). In other words, each construct and its measures in the research model do a great job in discriminating themselves from other constructs and their corresponding measures. The study gains further confidence on discriminant validity by examining the cross-loadings, which indicate that items are more strongly related to their own construct than to other constructs. In other words, each item loads more on its own construct than on other constructs and, therefore, all constructs share a substantial amount of variance with their own items (Chin, 1998b; Fornell and Bookstein, 1982). In all cases, the item's relationship to its own construct has a shared variance of more than $56 \%$ (i.e., $0.75 * 0.75$ ), which is substantial in magnitude in comparison with other constructs (Chin, 2010). Overall, the measurement model was considered satisfactory due to the evidence of adequate reliability (AVE >0.50, CR > 0.80) and convergent validity (loadings $>0.75$ ), as shown in Table 8, and discriminant validity $(\sqrt{A V E}>$ correlations $)$, as shown in Table 9 . The first-order measurement model was thus confirmed as satisfactory: it was then employed for testing the higher-order measurement model and the structural model which is described in the next sections.

Table 8: Assessment of First-Order, Reflective Model 


\begin{tabular}{|c|c|c|c|c|}
\hline Reflective Constructs & Items & Loadings & $\mathrm{CR}$ & AVE \\
\hline $\begin{array}{l}\text { BDA Planning } \\
\text { (BDAPL) }\end{array}$ & $\begin{array}{l}\text { BDAPL1 } \\
\text { BDAPL2 } \\
\text { BDAPL3 } \\
\text { BDAPL4 }\end{array}$ & $\begin{array}{l}0.918 \\
0.941 \\
0.915 \\
0.904\end{array}$ & 0.956 & 0.846 \\
\hline $\begin{array}{l}\text { BDA Investment Decision Making } \\
\text { (BDAID) }\end{array}$ & $\begin{array}{l}\text { BDAID1 } \\
\text { BDAID2 } \\
\text { BDAID3 } \\
\text { BDAID4 }\end{array}$ & $\begin{array}{l}0.885 \\
0.858 \\
0.889 \\
0.883 \\
\end{array}$ & 0.931 & 0.772 \\
\hline $\begin{array}{l}\text { BDA Coordination } \\
\text { (BDACO) }\end{array}$ & $\begin{array}{l}\text { BDACO1 } \\
\text { BDACO2 } \\
\text { BDACO3 } \\
\text { BDACO4 }\end{array}$ & $\begin{array}{l}0.873 \\
0.890 \\
0.856 \\
0.870 \\
\end{array}$ & 0.927 & 0.761 \\
\hline $\begin{array}{l}\text { BDA Control } \\
\text { (BDACT) }\end{array}$ & $\begin{array}{l}\text { BDACT1 } \\
\text { BDACT2 } \\
\text { BDACT3 } \\
\text { BDACT4 }\end{array}$ & $\begin{array}{l}0.870 \\
0.921 \\
0.902 \\
0.932 \\
\end{array}$ & 0.949 & 0.822 \\
\hline $\begin{array}{l}\text { BDA Connectivity } \\
\text { (BDACN) }\end{array}$ & $\begin{array}{l}\text { BDACN1 } \\
\text { BDACN2 } \\
\text { BDACN3 } \\
\text { BDACN4 }\end{array}$ & $\begin{array}{l}0.855 \\
0.769 \\
0.861 \\
0.851 \\
\end{array}$ & 0.902 & 0.697 \\
\hline $\begin{array}{l}\text { BDA Compatibility } \\
\text { (BDACM) }\end{array}$ & $\begin{array}{l}\text { BDACM1 } \\
\text { BDACM2 } \\
\text { BDACM3 } \\
\text { BDACM4 }\end{array}$ & $\begin{array}{l}0.908 \\
0.925 \\
0.885 \\
0.831\end{array}$ & 0.937 & 0.788 \\
\hline $\begin{array}{l}\text { BDA Modularity } \\
\text { (BDAMD) }\end{array}$ & $\begin{array}{l}\text { BDAMD1 } \\
\text { BDAMD2 } \\
\text { BDAMD3 } \\
\text { BDAMD4 }\end{array}$ & $\begin{array}{l}0.897 \\
0.873 \\
0.910 \\
0.822 \\
\end{array}$ & 0.902 & 0.701 \\
\hline $\begin{array}{l}\text { BDA Technology Management } \\
\text { Knowledge } \\
\text { (BDATM) }\end{array}$ & $\begin{array}{l}\text { BDATM1 } \\
\text { BDATM2 } \\
\text { BDATM3 } \\
\text { BDATM4 }\end{array}$ & $\begin{array}{l}0.908 \\
0.873 \\
0.919 \\
0.906 \\
\end{array}$ & 0.945 & 0.813 \\
\hline $\begin{array}{l}\text { BDA Technical Knowledge } \\
\text { (BDATK) }\end{array}$ & $\begin{array}{l}\text { BDATK1 } \\
\text { BDATK2 } \\
\text { BDATK3 } \\
\text { BDATK4 }\end{array}$ & $\begin{array}{l}0.884 \\
0.881 \\
0.889 \\
0.907 \\
\end{array}$ & 0.939 & 0.792 \\
\hline $\begin{array}{l}\text { BDA Business Knowledge } \\
\text { (BDABK) }\end{array}$ & $\begin{array}{l}\text { BDABK1 } \\
\text { BDABK2 } \\
\text { BDABK3 } \\
\text { BDABK4 }\end{array}$ & $\begin{array}{l}0.890 \\
0.932 \\
0.951 \\
0.962\end{array}$ & 0.965 & 0.873 \\
\hline
\end{tabular}




\begin{tabular}{|l|l|l|l|l|}
\hline BDA Relational Knowledge & BDARK1 & 0.917 & 0.949 & 0.822 \\
(BDARK) & BDARK2 & 0.930 & & \\
& BDARK3 & 0.893 & & \\
& BDARK4 & 0.885 & & \\
\hline Analytics Capability-Business & ACBSA1 & 0.936 & 0.960 & 0.857 \\
Strategy Alignment & ACBSA2 & 0.919 & & \\
(ACBSA) & ACBSA3 & 0.941 & & \\
& ACBSA4 & 0.907 & & \\
\hline Firm Performance & FPER1 & 0.939 & 0.960 & 0.859 \\
(FPER) & FPER2 & 0.924 & & \\
& FPER3 & 0.961 & & \\
\hline Formative construct & Items & Weights & t-value & VIF \\
& & & & \\
\hline Control Variables & Age & 0.580 & 1.841 & 1.184 \\
(COVA) & Gender & 0.439 & 1.517 & 1.017 \\
& education & 0.685 & 2.549 & 1.035 \\
& experience & 0.096 & 0.293 & 1.214 \\
& industry & -0.142 & 0.448 & 1.029 \\
& Firm size & 0.022 & 0.075 & 1.016 \\
\hline
\end{tabular}

Table 9: Descriptive Statistics, Correlations, and AVEs*

\begin{tabular}{|c|c|c|c|c|c|c|c|c|c|c|c|c|c|c|c|c|}
\hline Construct & Mean & $S D$ & $B D A P L$ & BDAID & $B D A C O$ & $B D A C T$ & $B D A C N$ & $B D A C M$ & $B D A M D$ & BDATM & BDATK & $B D A B K$ & BDARK & $A C B S A$ & FPER & COVA \\
\hline $\begin{array}{l}\text { BDA Planning } \\
\text { (BDAPL) }\end{array}$ & 4.899 & 1.367 & $0.912 *$ & & & & & & & & & & & & & \\
\hline $\begin{array}{l}\text { BDA Investment Decision } \\
\text { Making (BDAID) }\end{array}$ & 4.851 & 1.364 & 0.466 & $0.879 *$ & & & & & & & & & & & & \\
\hline $\begin{array}{ll}\text { BDA } & \text { Coordination } \\
\text { (BDACO) } & \end{array}$ & 4.603 & 1.358 & 0.390 & 0.319 & $0.872 *$ & & & & & & & & & & & \\
\hline BDA Control (BDACT) & 4.577 & 1.364 & 0.444 & 0.478 & 0.476 & $0.907 *$ & & & & & & & & & & \\
\hline
\end{tabular}




\begin{tabular}{|c|c|c|c|c|c|c|c|c|c|c|c|c|c|c|c|c|}
\hline $\begin{array}{ll}\text { BDA } & \text { Connectivity } \\
(\mathrm{BDACN}) & \end{array}$ & 4.528 & 1.445 & 0.397 & 0.379 & 0.362 & 0.348 & $0.835 *$ & & & & & & & & & \\
\hline $\begin{array}{ll}\text { BDA } & \text { Compatibility } \\
(\text { BDACM) } & \end{array}$ & 4.536 & 1.496 & 0.332 & 0.367 & 0.317 & 0.409 & 0.388 & $0.888 *$ & & & & & & & & \\
\hline $\begin{array}{ll}\text { BDA } & \text { Modularity } \\
\text { (BDAMD) } & \end{array}$ & 4.466 & 1.423 & 0.423 & 0.471 & 0.461 & 0.410 & 0.425 & 0.427 & $0.837 *$ & & & & & & & \\
\hline $\begin{array}{ll}\text { BDA } & \text { Technology } \\
\text { Management } & \text { Knowledge } \\
\text { (BDATM) } & \\
\end{array}$ & 4.845 & 1.279 & 0.364 & 0.356 & 0.417 & 0.407 & 0.369 & 0.370 & 0.440 & $0.902 *$ & & & & & & \\
\hline $\begin{array}{l}\text { Business } \quad \text { Technical } \\
\text { Knowledge (BDATK) }\end{array}$ & 4.881 & 1.354 & 0.346 & 0.417 & 0.346 & 0.402 & 0.363 & 0.348 & 0.459 & 0.586 & $0.890 *$ & & & & & \\
\hline $\begin{array}{ll}\text { BDA } & \text { Business } \\
\text { Knowledge (BDABK) }\end{array}$ & 4.962 & 1.309 & 0.396 & 0.351 & 0.370 & 0.430 & 0.353 & 0.368 & 0.358 & 0.527 & 0.481 & $0.934^{*}$ & & & & \\
\hline $\begin{array}{ll}\text { BDA } & \text { Relational } \\
\text { Knowledge (BDARK) }\end{array}$ & 4.851 & 1.308 & 0.314 & 0.332 & 0.370 & 0.387 & 0.391 & 0.338 & 0.348 & 0.524 & 0.510 & 0.576 & $0.906 *$ & & & \\
\hline $\begin{array}{lr}\text { Analytics } & \text { Capability- } \\
\text { Business } & \text { Strategy } \\
\text { Alignment } & \text { (ACBSA) }\end{array}$ & 4.778 & 1.229 & 0.352 & 0.375 & 0.359 & 0.441 & 0.331 & 0.366 & 0.362 & 0.335 & 0.476 & 0.436 & 0.441 & $0.926 *$ & & \\
\hline Firm Performance (FPER) & 4.652 & 1.269 & 0.330 & 0.376 & 0.347 & 0.370 & 0.312 & 0.361 & 0.362 & 0.315 & 0.391 & 0.313 & 0.315 & 0.457 & $0.927 *$ & \\
\hline $\begin{array}{l}\text { Control Variables } \\
\text { (COVA) }\end{array}$ & n.a. & n.a. & -0.088 & -0.204 & -0.107 & -0.123 & -0.074 & -0.169 & -0.160 & -0.112 & -0.084 & -0.127 & -0.131 & -0.128 & -0.207 & n.a. \\
\hline
\end{tabular}

*square root of AVE on the diagonal 


\subsection{Higher-Order Measurement Model}

In Table 10, the study estimated the measurement properties of the higher-order constructs, that is, the third-order BDAC construct and second-order management capability, technology capability, and talent capability constructs. The third-order BDAC construct consists of 44 items $(16+12+16)$ of which 16 items $(4+4+4+4)$ represent BDA planning capability, 12 items $(4+4+4)$ represent BDA technology capability, and 16 items $(4+4+4$ +4) represent talent capability. As higher-order constructs are reflective, the study confirmed that the loadings of items of both the third-order BDAC construct and the second-order constructs (management capability, technology capability, and talent capability) are significant at $\mathrm{p}<0.05$.

The degree of variance of the third-order BDAC construct was explained by its second-order antecedents, that is, BDAMAC (88\%), BDATEC (83\%), and BDATLC (90\%). Accordingly, the variances of the second-order constructs were explained by their corresponding first-order components (see Appendix 2). For example, the degree of explained variance of BDAMAC was explained by BDAPL (82\%), BDAID (79\%), BDACO (72\%), and BDACT (85\%). Similarly, BDATEC was explained by BDACN (75\%), BDACM (85\%), and BDAMD (81\%). Finally, BDATLC was explained by BDATM (86\%), BDATK (89\%), BDABK $(87 \%)$, and BDARK $(88 \%)$. All these path coefficients from the first-order to the second-order to the third-order constructs were significant at $\mathrm{p}<0.01$. 
Table 10: Assessment of the Higher-order, Reflective Model

\begin{tabular}{|c|c|c|c|c|c|c|c|c|}
\hline Models & Latent constructs & AVE & $\mathrm{CA}$ & $\mathrm{CR}$ & Dimensions & $\mathrm{B}$ & $R^{2}$ & $t$-statistic \\
\hline $\begin{array}{l}\text { Third- } \\
\text { order }\end{array}$ & $\begin{array}{l}\text { Big Data Analytics } \\
\text { Capability (BDAC) }\end{array}$ & 0.577 & 0.982 & 0.983 & $\begin{array}{l}\text { BDAMAC } \\
\text { BDATEC } \\
\text { BDATLC }\end{array}$ & $\begin{array}{l}0.938 \\
0.912 \\
0.948\end{array}$ & $\begin{array}{l}0.879 \\
0.831 \\
0.900\end{array}$ & $\begin{array}{l}70.756 \\
57.490 \\
86.239\end{array}$ \\
\hline \multirow[t]{3}{*}{$\begin{array}{l}\text { Second- } \\
\text { order }\end{array}$} & $\begin{array}{l}\text { BDA Management } \\
\text { Capability (BDAMAC) }\end{array}$ & 0.635 & 0.961 & 0.965 & $\begin{array}{l}\text { BDAPL } \\
\text { BDAID } \\
\text { BDACO } \\
\text { BDACT }\end{array}$ & $\begin{array}{l}0.903 \\
0.888 \\
0.850 \\
0.920\end{array}$ & $\begin{array}{l}0.815 \\
0.788 \\
0.723 \\
0.846\end{array}$ & $\begin{array}{l}47.238 \\
37.369 \\
24.860 \\
57.554\end{array}$ \\
\hline & $\begin{array}{l}\text { BDA Technology } \\
\text { Capability (BDATEC) }\end{array}$ & 0.600 & 0.932 & 0.942 & $\begin{array}{l}\text { BDACN } \\
\text { BDACM } \\
\text { BDAMD }\end{array}$ & $\begin{array}{l}0.864 \\
0.919 \\
0.897\end{array}$ & $\begin{array}{l}0.747 \\
0.845 \\
0.805\end{array}$ & $\begin{array}{l}24.312 \\
55.863 \\
38.407\end{array}$ \\
\hline & $\begin{array}{l}\text { BDA Talent Capability } \\
\text { (BDATLC) }\end{array}$ & 0.722 & 0.974 & 0.976 & $\begin{array}{l}\text { BDATM } \\
\text { BDATK } \\
\text { BDABK } \\
\text { BDARK }\end{array}$ & $\begin{array}{l}0.944 \\
0.926 \\
0.934 \\
0.938\end{array}$ & $\begin{array}{l}0.858 \\
0.891 \\
0.872 \\
0.881\end{array}$ & $\begin{array}{l}61.828 \\
85.388 \\
59.852 \\
95.354\end{array}$ \\
\hline
\end{tabular}

\subsection{Structural Model}

To assess the validity of the structural model, the study estimated the relationship between the higher-order BDAC and FPER. The results provide a standardized beta of 0.709 for the BDAC-FPER path in the main, thus supporting H1. In order to identify the moderating effect of ACBSA on FPER, we applied PLS product-indicator approach (Chin et al., 2003). We created the interaction construct by multiplying the hierarchical BDAC construct with ACBSA construct following the guidelines of Chin et al. (2003). Thus, to estimate the interaction effect, we separately estimated the influence of BDAC on FPER, ACBSA on FPER and the impact of BDAC*ACBSA (interaction variable) on FPER. For the interaction model, the results provide us a standardized beta of 0.261 for BDAC-FPER $(\mathrm{p}<0.01), 0.542$ for ACBSA-FPER $(\mathrm{p}<0.01)$ and $0.153(\mathrm{p}<0.05)$ for BDAC*ACBSA-FPER respectively. We confirm the significance of the moderator because the path coefficient of the BDAC*ACBSA-FPER is significant, independently of BDAC-FPER and ACBSA-FPER relationships in the interaction model (Henseler and Fassott, 2010). According to the guidelines of Cohen (1988), the size of the moderating effect is medium $\left(f^{2}=0.23\right)$ but 
significant at $\mathrm{p}<0.05$. Thus, the results provide support for the $\mathrm{H} 2$. In Table 11 , we evaluated the main model (m) with the interaction model (i) using an incremental $\mathrm{F}$ test to investigate whether inclusion of moderating variable (ACBSA) significantly enhances the $\mathrm{R}^{2}$ for FPER. The findings confirm a superior prediction power of the interaction model, which is reflected in firm performance $\left(\Delta \mathrm{R}^{2}=0.093, \mathrm{f}^{2}=0.23, \mathrm{p}<0.01\right)$. Similarly, we investigated the impact of control variables (COVA) on FPER, however, the results show insignificant impact of COVA as the $\mathrm{R}^{2}$ change is very small after including this construct in the model.

Table 11: Results of Structural Model

\begin{tabular}{|c|c|c|c|c|c|}
\hline Main Model & $\begin{array}{l}\text { Path } \\
\text { coefficients }\end{array}$ & $\begin{array}{l}\text { Standard } \\
\text { error }\end{array}$ & $t$-statistic & $R^{2}$ & $f^{2}$ \\
\hline $\mathrm{BDAC} \longrightarrow$ FPER & 0.709 & 0.053 & 13.265 & 0.503 & n.a. \\
\hline Interaction Model & Path & Standard & $t$-statistic & $R^{2}$ & \multirow{3}{*}{$\begin{array}{l}f^{2}=\frac{R_{i}^{2}-R_{m}^{2}}{1-R_{i}^{2}} \\
=\frac{0.596-0.503}{1-0.596}=0.23 \\
\begin{array}{l}\text { (Here, } i=\text { interaction } \\
\text { model, } m=\text { main effect } \\
\text { model) }\end{array}\end{array}$} \\
\hline $\begin{array}{l}\mathrm{BDAC} \longrightarrow \text { FPER } \\
\mathrm{ACBSA} \longrightarrow \text { FPER }\end{array}$ & $\begin{array}{l}0.261 \\
0.542\end{array}$ & $\begin{array}{l}0.102 \\
0.102\end{array}$ & $\begin{array}{l}2.558 \\
5.319\end{array}$ & 0.596 & \\
\hline$\longrightarrow$ FPER & 0.153 & 0.079 & 1.937 & & \\
\hline Control Model & Path & Standard & $t$-statistic & $R^{2}$ & \multirow{3}{*}{$\begin{array}{l}f^{2}=\frac{\boldsymbol{R}_{c}^{2}-\boldsymbol{R}_{m}^{2}}{1-\boldsymbol{R}_{c}^{2}} \\
=\frac{0.514-0.503}{1-0.514}=0.02 \\
\begin{array}{l}\text { (Here, } c=\text { model with } \\
\text { control variables, } \\
\text { model, } m=\text { main effect } \\
\text { model) }\end{array}\end{array}$} \\
\hline$\longrightarrow$ FPER & 0.694 & 0.053 & 13.048 & 0.514 & \\
\hline COVA $\longrightarrow$ FPER & -0.101 & 0.076 & 1.335 & & \\
\hline
\end{tabular}




\subsection{Additional Analyses}

The findings of the study confirm the impact of BDAC and ACBSA on FPER, thereby ensuring the nomological validity of the overall research model. The study also conducted few additional analyses to ensure overall validity of the findings. First, to address the concern of non-response bias, we checked the profiles of the survey respondents and those on the panel in terms of organization size and industry, and no non-response bias was found through the chi-square tests (Kim et al., 2012). We also compared the early (20 percent) and late (20 percent) response groups, and the paired t-test did not provide any significant difference on the survey items between two groups. Second, we checked common method variance (CMV) by applying Harman's one-factor test (Podsakoff and Organ, 1986) on the 11 first-order constructs and the results did not provide any significant common factor loading on all the measures. Third, we applied Stone-Geisser's $Q^{2}$ to test the predictive validity of the model (Akter et al., 2011). Using the cross-validated redundancy approach (omission distance $=7$ ), this study obtained a $Q^{2} 0.503$ for FPER, which adequately demonstrate the predictive validity of the BDAC construct on FPER in the big data environment (Chin, 2010). Finally, the study conducted power analysis $(1-\beta)$ to validate the empirical findings on the 152 responses in the sample. Power (1- $\beta$ ) indicates the probability of successfully rejecting a null hypothesis (Cohen, 1992). Using G*Power 3.1.3 by Faul et al. (2009), the study conducted the power test (post hoc) to estimate the validity of the hypothesized relationships. Cohen (1988) suggests that a threshold level of 0.80 be used as estimated power for behavioral research. The study estimated the power of 0.99 for the research model with the sample size of $152(\mathrm{~N}), 0.05$ significance level $(\alpha)$ and 0.10 effect size (ES). The size of estimated power (0.99) compellingly exceeds the cut-off value of 0.80 (Cohen, 1992), confirming that the associations are truly significant. 


\subsection{Summary of Findings}

This study developed a hierarchical BDAC model consisting of three dimensions: management capability, technology capability, and talent capability. The BDAC model was developed to capture multidimensional capability in the big data environment and to frame its impact on FPER in a nomological network. The findings show that the higher-order BDAC construct has a strong significant impact on FPER. This result confirms that the emphasis on BDAC is the perfect starting point for identifying and solving emerging big data challenges. These results also put forward the concept of the 'entanglement view' in visualizing the multidimensional capability challenges in the broader data economy.

\section{Discussion}

Big data analytics capability (BDAC) was found to have a positive association with all the primary dimensions with BDA talent capability (BDATLC) emerging as the strongest. This finding suggests that greater gains in overall BDAC can be achieved by BDATLC, which is evident in 'born-through-analytics companies' such as Facebook and Amazon and their well-developed recruiting approaches for analytics talent (Court, 2015). In addition, BDA management capability (BDAMAC) was identified as a significant dimension indicating that achieving sustainable competitive advantage with analytics relies heavily on decision makers. A recent big data study (involving 2,037 professionals and interviews with more than 30 executives in 100 countries and 25 industries) reflects the importance of analytics management as $87 \%$ of its respondents suggest focusing on elevating their organizations to the next level of analytics management (Kiron et al., 2014).

BDA technology capability (BDATEC) was identified as a key predictor of BDAC, emphasizing the need for versatility of the analytics platform so that it connects data from various functions across the firm, ensures information flow, and develops robust models. In the big data environment, technology flexibility is critical for embracing voluminous and 
valuable data from a variety of sources, thus enabling firms to swiftly implement models (Barton and Court, 2012). Although the study has prioritized the importance of the overall BDAC dimensions in terms of explained variance, it recommends that equal attention should be paid to all the dimensions to achieve successful application in big data functions, for example, logistics, risk management, pricing, customer service, and personnel management. Overall, the findings of the structural model confirm that BDAC is a significant predictor of FPER (explaining 50\% of the variance). These findings confirm ACBSA as the significant moderator or the necessary condition for strong firm performance (FPER). The interaction model explained around $60 \%$ of the variance. Overall, these findings suggest that big data firms should consider higher-order BDAC and ACBSA as important strategic antecedents to influence firm performance (FPER).

\subsection{Theoretical Contributions}

This study makes several contributions to BDAC research. Firstly, the study develops the scale of three primary BDAC constructs, and 11 sub-constructs and their associated measurement items against the backdrop of capability research in big data analytics (BDA). The findings therefore contribute to answering "What capabilities (technical and nontechnical) should an organization acquire to succeed in big data efforts?" arguably one of the most interesting questions in the field of big data research today (Phillips-Wren et al., 2015, p. 465). The empirical findings of our study answer this question, and are consistent with the conceptual findings of Kiron et al. (2014, p.10) who state that "an effective analytics culture is built on the backs of more advanced data management processes, technologies and talent". Secondly, despite the paucity of empirical modeling in big data research, our research extends this stream by conceptualizing a multidimensional BDAC model drawing on the RBT and sociomaterialism which substantiate the fact that BDAC is a hierarchical construct having a strong influence on firm performance (FPER). This research applies RBT as a unifying 
paradigm for combining other theories (e.g., sociomaterialism and IT capability) and presents a parsimonious foundation for multiple theoretical perspectives. Using this foundation, our research provides a hierarchical model for integrating multiple and diverse capabilities into one framework to model their relative and synergistic effects on FPER. The emerging BDA research has been struggling to encapsulate and prove the significance of BDAC as a source of firm performance. Our research specifically addresses this challenge by presenting the third-order BDAC model to capture the variations in firm performance (FPER). Thirdly, by applying the RBT and the sociomaterialism perspective in conceptualizing BDAC within the big data environment, our research proves its utility in portraying the entanglement phenomenon in BDAC dynamics. The study's research model has provided evidence of its power not only in proving structural parsimony but also in explaining theorized interactions which have been manifested at the first-order, second-order and third-order constructs. Fourthly, the study contributes by exploring the dimensions and sub-dimensions of BDAC and providing possible solutions to the challenges of such dimensions.

Finally, the study adds further theoretical rigor by analyzing and measuring the moderating effect of ACBSA on FPER. This finding confirms that the fit between capability and strategy can help big data organizations to perceive, assess, and act upon their micro and macro environments (Constantiou and Kallinikos, 2014). The results on the moderating effect of strategic alignment further clarify the conceptual model and extend the theoretical contributions by framing the impact of complex, hierarchical BDAC model on firm performance (Iacobucci, 2009). Overall, the findings of the study help to minimize confusions regarding the role of strategic alignment in the RBT framework (Teece, 2014). 


\subsection{Managerial Contributions}

With the growing importance of data-oriented or evidence-based organizations, our study has important implications for practice. Firstly, our study suggests that BDAC is an important enabler of improved FPER, thus confirming the relationship between high-level BDAC and firm performance (FPER). The results indicate that the improvement of overall BDAC can be linked with dimensional and sub-dimensional levels. As an example, BDA management capability (BDAMAC) could be enhanced by improving the quality of planning, investment, coordination, and control. Similarly, BDA technology capability (BDATEC) could be improved by enhancing the performance of the BDA platform in terms of connectivity, compatibility, and modularity. Finally, BDA talent capability (BDATLC) could be upgraded by recruitment and/or training to achieve better skills and knowledge of the workforce. Therefore, the linkages in the model provide managers with an understanding of the antecedents of overall BDAC and its relationship with the individual capability dimensions. Indeed, the overall BDAC model development within a data-oriented organization has the potential to foster what Kiron and Shockley (2012) call "competitive analytics or analytics that delivers advantage in the marketplace" (p.59).

Secondly, the findings of our study emphasize not only the importance of BDAC development but also a strong alignment between BDAC and ACBSA in order to achieve improved firm performance (FPER). These findings are consistent with (Court, 2015) who found that organizations could increase operating margins by $60 \%$ through ensuring a tight alignment between analytics efficiency and strategy. Prior studies in IT capability research also support the importance of capability-strategy alignment by focusing on business process agility (Chen et al., 2014), organizational agility (Lu and Ramamurthy, 2011), and processoriented dynamic capabilities (Kim et al., 2011). 
Thirdly, the findings of the study have huge practical implications for various industries developing BDAC, such as retail, manufacturing, healthcare, and public sector administration. For example, by improving BDAC and aligning strategy, managers could better serve customer needs (79\%); increase sales and revenue (76\%); create new products and services (70\%); and expand into new markets (72\%), with the help of quality information and robust insights (Columbus, 2014b). According to Wixom et al. (2013, p.120), “... once BA [Big data analytics] capabilities are established, business value is maximized by using practices that drive speed to insight and by making BA usage pervasive across the enterprise". Consequently, there is a growing focus on the BDAC-ACBSA-FPER link in the BDA environment across various industries.

\subsection{Limitations and Future Research Directions}

With regard to the limitations of the study, firstly, its scope was limited to exploring BDAC dimensions and modeling the impact of BDAC on FPER with ACBSA as a moderator. It would be interesting to integrate more variables such as business process agility (Chen et al., 2014) and process-oriented dynamic capabilities (Kim et al., 2011) into future studies. Secondly, certain burning issues (e.g., the analytics climate, privacy, surveillance and democracy) could not be encapsulated into this study but might be investigated in future research. According to Ekbia et al. (2015), "big data is dark data"; thus, it needs to be investigated in a meaningful balanced manner by applying the right talent, technology, and strategy. Thirdly, this study used a 7-point Likert scale to measure all the items, which may introduce the so-called 'acquiescence bias' (Chin et al., 2008). Consequently, future research could consider using the 9-point scale of fast form items with the two-anchor points ranging from -4 to +4 as recommended by Chin et al. (2008). Finally, the study does not evaluate unobserved heterogeneity in the structural equation model (SEM). Therefore, further research 
could attempt to integrate the evaluation of the unobserved heterogeneity into its data analysis strategy.

\subsection{Conclusion}

This research builds a theory of BDAC strategy that shows how to leverage the BDAC dimensions and sub-dimensions in order to build an overall BDAC climate. Although several studies highlight the importance of management, technology and talent capability in big data environment, our work illuminates the role of RBT and entanglement view in proposing an integrated BDAC model and its overall impact on firm performance. With the growing interests in business analytics across various industries, the current study advances BDAC conceptualization and the role of ACBSA in enhancing FPER. A notable strength of the current study is that data were collected from multiple industries to empirically test the model.

Overall, the study leads to a better understanding of capability-strategy-performance in data economy and is likely to open new avenues of research into academic and corporate policy and practices.

\section{References}

Abbasi, A., Sarker, S., Chiang, R.H.L., 2016. Big Data Research in Information Systems: Toward an Inclusive Research Agenda. Journal of the Association for Information Systems 17, i-xxxii.

Agarwal, R., Dhar, V., 2014. Editorial—Big Data, Data Science, and Analytics: The Opportunity and Challenge for IS Research. Information Systems Research 25, 443-448.

Akter, S., D'Ambra, J., Ray, P., 2011. An evaluation of PLS based complex models: The roles of power analysis, predictive relevance and GoF index. AMCIS 2011 Proceedings-All Submissions.

Alismaili, S., Li, M., Shen, J., He, Q., 2016. A Multi Perspective Approach for Understanding the Determinants of Cloud Computing Adoption among Australian SMEs. arXiv preprint arXiv: 1606.00745

Amit, R., Schoemaker, P.J., 1993. Strategic assets and organizational rent. Strategic management journal 14, 33-46.

Barney, J., 1991. Firm resources and sustained competitive advantage. Journal of management 17, 99120.

Barney, J., Wright, M., Ketchen, D.J., 2001. The resource-based view of the firm: Ten years after 1991. Journal of management 27, 625-641.

Barney, J.B., Arikan, A.M., 2001. The resource-based view: Origins and implications. Handbook of strategic management 124188. 
Barney, J.B., Clark, D.N., 2007. Resource-based theory: Creating and sustaining competitive advantage. Oxford University Press Oxford.

Barney, J.B., Hesterly, W.S., 2012. Strategic management and competitive advantage: concepts and cases. Pearson/Prentice Hall Upper Saddle River, NJ.

Barton, D., Court, D., 2012. Making advanced analytics work for you. Harvard business review 90, 78.

Becker, J., Beverungen, D.F., Knackstedt, R., 2010. The challenge of conceptual modeling for product-service systems: status-quo and perspectives for reference models and modeling languages. Information Systems and E-Business Management 8, 33-66.

Beulke, D., 2011. Big Data Impacts Data Management: The 5 Vs of Big Data.

Bharadwaj, A.S., 2000a. A resource-based perspective on information technology capability and firm performance: an empirical investigation. MIS quarterly 24, 169-196.

Bharadwaj, A.S., 2000b. A Resource-Based Perspective on Information Technology Capability and Firm Performance: An Empirical Investigation. MIS Quarterly 24, 169-196.

Bhatt, G.D., Grover, V., 2005. Types of information technology capabilities and their role in competitive advantage: an empirical study. Journal of Management Information Systems 22, 253-277.

Boar, B.H., 1995. Cost-effective strategies for client/server systems. John Wiley \& Sons, Inc.

Boynton, A.C., Zmud, R.W., Jacobs, G.C., 1994. The influence of IT management practice on IT use in large organizations. Mis Quarterly, 299-318.

Broadbent, M., Weill, P., St. Clair, D., 1999. The implications of information technology infrastructure for business process redesign. MIS quarterly, 159-182.

Chen, Y., Wang, Y., Nevo, S., Jin, J., Wang, L., Chow, W.S., 2014. IT capability and organizational performance: the roles of business process agility and environmental factors. European Journal of Information Systems 23, 326-342.

Chin, W.W., 1998a. Commentary: Issues and opinion on structural equation modeling. MIS Quarterly.

Chin, W.W., 1998b. The partial least squares approach for structural equation modeling.

Chin, W.W., 2010. How to write up and report PLS analyses. Handbook of partial least squares, 655690.

Chin, W.W., Johnson, N., Schwarz, A., 2008. A Fast Form Approach to Measuring Technology Acceptance and Other Constructs. MIS Quarterly 32, 687-703.

Chin, W.W., Marcolin, B.L., Newsted, P.R., 2003. A partial least squares latent variable modeling approach for measuring interaction effects: Results from a Monte Carlo simulation study and an electronic-mail emotion/adoption study. Information Systems Research 14, 189-217.

Clemons, E.K., Row, M.C., 1991. Sustaining IT advantage: the role of structural differences. MIS quarterly, 275-292.

Cohen, J., 1988. Statistical power analysis for the behavioral sciences. Routledge Academic.

Cohen, J., 1992. Statistical power analysis. Current directions in psychological science 1, 98-101.

Columbus, L., 2014a. 84\% Of Enterprises See Big Data Analytics Changing Their Industries' Competitive Landscapes In The Next Year, Forbes.

Columbus, L., 2014b. Making Analytics Accountable: 56\% Of Executives Expect Analytics to Contribute To 10\% Or More Growth in 2014, Forbes.

Constantiou, I.D., Kallinikos, J., 2014. New games, new rules: big data and the changing context of strategy. Journal of Information Technology.

Court, D., 2015. Getting big impact from big data, McKinsey Quarterly, pp. 1-8. 
Crook, T.R., Ketchen, D.J., Combs, J.G., Todd, S.Y., 2008. Strategic resources and performance: a meta-analysis. Strategic management journal 29, 1141-1154.

Davenport, T.H., 2006. Competing on analytics. harvard business review 84, 98-107.

Davenport, T.H., Barth, P., Bean, R., 2012. How 'Big Data'is Different. MIT Sloan Management Review 54, 43-46.

Davenport, T.H., Harris, J.G., 2007a. Competing on analytics: the new science of winning. Harvard Business School Press.

Davenport, T.H., Harris, J.G., 2007b. The dark side of customer analytics. Harvard Business Review 85, 37-+.

Davenport, T.H., Patil, D., 2012. Data scientist: the sexiest job of the 21st century. Harvard business review 90, 70-77.

Dehning, B., Richardson, V.J., 2002. Returns on investments in information technology: A research synthesis. Journal of Information Systems 16, 7-30.

DeSanctis, G., Jackson, B.M., 1994. Coordination of information technology management: Teambased structures and computer-based communication systems. Journal of Management Information Systems, 85-110.

Duncan, N.B., 1995. Capturing flexibility of information technology infrastructure: A study of resource characteristics and their measure. Journal of Management Information Systems, 37-57.

Efron, B., Tibshirani, R., 1993. An introduction to the bootstrap. Chapman \& Hall/CRC.

Ekbia, H., Mattioli, M., Kouper, I., Arave, G., Ghazinejad, A., Bowman, T., Suri, V.R., Tsou, A., Weingart, S., Sugimoto, C.R., 2015. Big data, bigger dilemmas: A critical review. Journal of the Association for Information Science and Technology.

Faul, F., Erdfelder, E., Buchner, A., Lang, A.-G., 2009. Statistical power analyses using G* Power 3.1: Tests for correlation and regression analyses. Behavior Research Methods 41, 1149-1160.

Fornell, C., Bookstein, F.L., 1982. Two structural equation models: LISREL and PLS applied to consumer exit-voice theory. Journal of Marketing Research, 440-452.

Fornell, C., Larcker, D.F., 1981. Evaluating structural equation models with unobservable variables and measurement error. Journal of Marketing Research, 39-50.

Forrester, 2012. The Big Deal About Big Data For Customer Engagement Business: Leaders Must Lead Big Data Initiatives To Derive Value.

Gartner, 2014. Gartner Says Worldwide IT Spending on Pace to Grow 3.2 Percent in 2014.

Gentile, B., 2012. Top 5 Myths About Big Data.

George, G., Haas, M.R., Pentland, A., 2014. Big data and management. Academy of Management Journal 57, 321-326.

Gobble, M.M., 2013. Big Data: The Next Big Thing in Innovation. Research Technology Management 56, 64-66.

Goes, P.B., 2014. Big Data and IS Research. MIS Quarterly 38, iii-viii.

Grant, R.M., 1991. The resource-based theory of competitive advantage: implications for strategy formulation. Knowledge and Strategy.(Ed. M. Zack) pp, 3-23.

Grant, R.M., 2002. The resource-based theory of competitive advantage. Strategy: Critical Perspectives on Business and Management 135.

Hair, J.F., Hult, G.T.M., Ringle, C., Sarstedt, M., 2013. A primer on partial least squares structural equation modeling (PLS-SEM). SAGE Publications, Incorporated. 
Hair, J.F., Ringle, C.M., Sarstedt, M., 2011. PLS-SEM: Indeed a silver bullet. The Journal of Marketing Theory and Practice 19, 139-152.

Hair Jr, J.F., Hult, G.T.M., Ringle, C., Sarstedt, M., 2013. A primer on partial least squares structural equation modeling (PLS-SEM). Sage Publications.

Henseler, J., Fassott, G., 2010. Testing moderating effects in PLS path models: An illustration of available procedures, Handbook of partial least squares. Springer, pp. 713-735.

Iacobucci, D., 2009. Everything you always wanted to know about SEM (structural equations modeling) but were afraid to ask. Journal of Consumer Psychology 19, 673-680.

IBM, 2012. What is big data?

IDC, 2012. The Digital Universe in 2020: Big Data, Bigger Digital Shadows, and Biggest Growth in the Far East.

Jiang, J.J., Klein, G., Slyke, C.V., Cheney, P., 2003. A note on interpersonal and communication skills for IS professionals: Evidence of positive influence. Decision Sciences 34, 799-812.

Johnson, J.E., 2012. BIG DATA + BIG ANALYTICS = BIG OPPORTUNITY. Financial Executive $28,50-53$.

Kallinikos, J., 2007. The consequences of information: Institutional implications of technological change. Edward Elgar Publishing.

Karimi, J., Somers, T.M., Gupta, Y.P., 2001. Impact of information technology management practices on customer service. Journal of Management Information Systems 17, 125-158.

Kauffman, R.J., Srivastava, J., Vayghan, J., 2012. Business and data analytics: New innovations for the management of e-commerce. Electronic Commerce Research and Applications 11, 85-88.

Kim, G., Shin, B., Kim, K.K., Lee, H.G., 2011. IT Capabilities, Process-Oriented Dynamic Capabilities, and Firm Financial Performance Journal of the Association for Information Systems 12, 487-517.

Kim, G., Shin, B., Kwon, O., 2012. Investigating the Value of Sociomaterialism in Conceptualizing IT Capability of a Firm. Journal of Management Information Systems 29, 327-362.

Kiron, D., Prentice, P.K., Ferguson, R.B., 2014. The analytics mandate. MIT Sloan management review 55, 1-25.

Kiron, D., Shockley, R., 2012. Creating Business Value with Analytics. MIT Sloan Management Review 53, 57-63.

Kozlenkova, I.V., Samaha, S.A., Palmatier, R.W., 2014. Resource-based theory in marketing. Academy of Marketing Science. Journal 42, 1-21.

Latour, B., 2005. Reassembling the social-an introduction to actor-network-theory. Reassembling the Social-An Introduction to Actor-Network-Theory, by Bruno Latour, pp. 316. Foreword by Bruno Latour. Oxford University Press, Sep 2005. ISBN-10: 0199256047. ISBN-13: 97801992560441.

Lavalle, S., Lesser, E., Shockley, R., Hopkins, M.S., Kruschwitz, N., 2011. Big Data, Analytics and the Path From Insights to Value. Mit Sloan Management Review 52, 21-32.

Lee, D.M., Trauth, E.M., Farwell, D., 1995. Critical skills and knowledge requirements of IS professionals: a joint academic/industry investigation. MIS quarterly, 313-340.

Li, E.Y., Jiang, J.J., Klein, G., 2003. The impact of organizational coordination and climate on marketing executives' satisfaction with information systems services. Journal of the Association for Information Systems 4, 4.

Lioukas, C.S., Reuer, J.J., Zollo, M., 2016. Effects of Information Technology Capabilities on Strategic Alliances: Implications for the Resource-Based View. Journal of Management Studies 53, 161-183. 
Lu, Y., Ramamurthy, K., 2011. Understanding the link between information technology capability and organizational agility: an empirical examination. MIS Quarterly 35, 931-954.

Lunden, I., 2013. Forrester: \$2.1 Trillion Will Go Into IT Spend In 2013; Apps And The U.S. Lead The Charge.

Makadok, R., 1999. Interfirm differences in scale economies and the evolution of market shares. Strategic Management Journal 20, 935-952.

Manyika, J., Chui, M., Brown, B., Bughin, J., Dobbs, R., Roxburgh, C., Byers, A.H., 2011. Big data: the next frontier for innovation, competition and productivity. McKinsey Global Institute.

Mata, F.J., Fuerst, W.L., Barney, J.B., 1995. Information technology and sustained competitive advantage: a resource-based analysis. MIS quarterly, 487-505.

McAfee, A., Brynjolfsson, E., 2012. Big data: the management revolution. Harvard business review, $60-66,68,128$.

Melville, N., Kraemer, K., Gurbaxani, V., 2004. INFORMATION TECHNOLOGY AND ORGANIZATIONAL PERFORMANCE: AN INTEGRATIVE MODEL OF IT BUSINESS VALUE. MIS Quarterly 28, 283-322.

Mithas, S., Lee, M.R., Earley, S., Murugesan, S., Djavanshir, R., 2013. Leveraging Big Data and Business Analytics. IT Professional 15, 18-20.

Morgan, N.A., Slotegraaf, R.J., Vorhies, D.W., 2009. Linking marketing capabilities with profit growth. International Journal of Research in Marketing 26, 284-293.

Oracle, 2012. Big data for the Enterprise.

Orlikowski, W.J., 2007. Sociomaterial practices: Exploring technology at work. Organization studies $28,1435-1448$.

Orlikowski, W.J., Scott, S.V., 2008. 10 Sociomateriality: Challenging the Separation of Technology, Work and Organization. The academy of management annals 2, 433-474.

Pavlou, P.A., El Sawy, O.A., 2006. From IT leveraging competence to competitive advantage in turbulent environments: The case of new product development. Information Systems Research 17, 198-227.

Peteraf, M.A., 1993. The cornerstones of competitive advantage: a resource-based view. Strategic management journal 14, 179-191.

Peteraf, M.A., Barney, J.B., 2003. Unraveling the resource-based tangle. Managerial and decision economics 24, 309-323.

Phillips-Wren, G., Iyer, L.S., Kulkarni, U., Ariyachandra, T., 2015. Business Analytics in the Context of Big Data: A Roadmap for Research. Communications of the Association for Information Systems $37,23$.

Piccoli, G., Ives, B., 2005. Review: IT-dependent strategic initiatives and sustained competitive advantage: a review and synthesis of the literature. Mis Quarterly 29, 747-776.

Podsakoff, P.M., Organ, D.W., 1986. Self-reports in organizational research: Problems and prospects. Journal of management 12, 531-544.

Porter, M.E., Millar, V.E., 1985. How information gives you competitive advantage. Harvard Business Review, Reprint Service.

Powell, T.C., Dent-Micallef, A., 1997. Information technology as competitive advantage: The role of human, business, and technology resources. Strategic management journal 18, 375-405.

Ramaswamy, S., 2013. What the Companies Winning at Big Data Do Differently. Bloomberg, June: http://www. bloomberg. com/news/2013-06-25/what-the-companies-winning-at-big-data-dodifferently. html. 
Ransbotham, S., Kiron, D., Prentice, P.K., 2015. Minding the Analytics Gap. MIT Sloan Management Review 56, 63-68.

Reinartz, W.J., Kumar, V., 2003. The impact of customer relationship characteristics on profitable lifetime duration. Journal of marketing 67, 77-99.

Ringle, C., Sarstedt, M., Straub, D., 2012. A critical look at the use of PLS-SEM in MIS quarterly. MIS Quarterly (MISQ) 36.

Ringle, C.M., Wende, S., Becker, J.-M., 2014. SmartPLS 3. SmartPLS.

Ross, J.W., Beath, C.M., Goodhue, D.L., 1996. Develop long-term competitiveness through IT assets. MIT Sloan Management Review 38, 31.

Russom, P., 2011. The Three Vs of Big Data Analytics. TDWI.

Ryan, S.D., Harrison, D.A., Schkade, L.L., 2002. Information-technology investment decisions: when do costs and benefits in the social subsystem matter? Journal of Management Information Systems 19, $85-128$

Sabherwal, R., 1999. The Relationship Between Information System Planning Sophistication and Information System Success: An Empirical Assessment*. Decision Sciences 30, 137-167.

Santhanam, R., Hartono, E., 2003. Issues in linking information technology capability to firm performance. MIS quarterly, 125-153.

Schroeck, M., Shockley, R., Smart, J., Romero-Morales, D., Tufano, P.P., 2012. Analytics: The realworld use of big data. IBM Institute for Business Value, NY, USA.

Segars, A.H., Grover, V., 1999. Profiles of strategic information systems planning. Information Systems Research 10, 199-232.

Setia, P., Patel, P.C., 2013. How information systems help create OM capabilities: Consequents and antecedents of operational absorptive capacity. Journal of Operations Management 31, 409-431.

Srinivasan, U., Arunasalam, B., 2013. Leveraging Big Data Analytics to Reduce Healthcare Costs.

Stein, M.-K., Newell, S., Wagner, E.L., Galliers, R.D., 2014. Felt quality of sociomaterial relations: Introducing emotions into sociomaterial theorizing. Information and Organization 24, 156-175.

Strawn, G.O., 2012. Scientific Research: How Many Paradigms? EDUCAUSE Review 47, 26.

Teece, D.J., 2014. The foundations of enterprise performance: Dynamic and ordinary capabilities in an (economic) theory of firms. The Academy of Management Perspectives 28, 328-352.

Tenenhaus, M., Vinzi, V.E., Chatelin, Y.-M., Lauro, C., 2005. PLS path modeling. Computational statistics \& data analysis 48, 159-205.

Terry Anthony Byrd, D.E.T., 2000. Measuring the flexibility of information technology infrastructure: Exploratory analysis of a construct. Journal of Management Information Systems 17, 167-208.

Tesch, D., Jiang, J.J., Klein, G., 2003. The impact of information system personnel skill discrepancies on stakeholder satisfaction. Decision Sciences 34, 107-129.

Tippins, M.J., Sohi, R.S., 2003. IT competency and firm performance: is organizational learning a missing link? Strategic Management Journal 24, 745-761.

Verhoef, P.C., Franses, P.H., Hoekstra, J.C., 2001. The impact of satisfaction and payment equity on cross-buying: A dynamic model for a multi-service provider. Journal of Retailing 77, 359-378.

Wamba, S.F., Akter, S., Edwards, A., Chopin, G., Gnanzou, D., 2015. How 'big data'can make big impact: Findings from a systematic review and a longitudinal case study. International Journal of Production Economics 165, 234-246.

Wetzels, M., Odekerken-Schroder, G., Van Oppen, C., 2009. Using PLS path modeling for assessing hierarchical construct models: guidelines and empirical illustration. MIS Quarterly 33, 177. 
Wixom, B.H., Yen, B., Relich, M., 2013. Maximizing value from business analytics. MIS Quarterly Executive 12, 111-123. 


\section{Appendix 1: Survey Measures}

\begin{tabular}{|c|c|c|c|c|c|c|}
\hline $\begin{array}{l}\text { 2nd-order } \\
\text { constructs }\end{array}$ & Type & $\begin{array}{l}\text { 1st-order } \\
\text { constructs }\end{array}$ & Type & $\begin{array}{l}\text { Item } \\
\text { labels }\end{array}$ & Items & Sources \\
\hline \multirow{16}{*}{$\begin{array}{l}\text { Big data } \\
\text { analytics } \\
\text { management } \\
\text { capabilities } \\
\text { (BDAMC) }\end{array}$} & \multirow{16}{*}{ 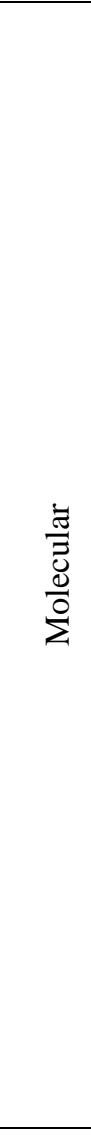 } & \multirow{4}{*}{$\begin{array}{l}\text { Big data } \\
\text { analytics } \\
\text { Planning }\end{array}$} & Reflective & BDAPL1 & $\begin{array}{l}\text { We continuously examine the innovative opportunities for the strategic use of big data } \\
\text { analytics. }\end{array}$ & \multirow{4}{*}{$\begin{array}{l}\text { (Boynton et al., } \\
\text { 1994; Karimi et } \\
\text { al., 2001; Kim et } \\
\text { al., 2012; } \\
\text { Sabherwal, 1999; } \\
\text { Segars and } \\
\text { Grover, 1999) }\end{array}$} \\
\hline & & & Reflective & BDAPL2 & We enforce adequate plans for the introduction and utilization of big data analytics. & \\
\hline & & & Reflective & BDAPL3 & We perform big data analytics planning processes in systematic and formalized ways. & \\
\hline & & & Reflective & BDAPL4 & We frequently adjust big data analytics plans to better adapt to changing conditions & \\
\hline & & \multirow{4}{*}{$\begin{array}{l}\text { Big data } \\
\text { analytics } \\
\text { Investment } \\
\text { Decision } \\
\text { Making }\end{array}$} & Reflective & BDAID1 & $\begin{array}{l}\text { When we make big data analytics investment decisions, we think about and estimate the } \\
\text { effect they will have on the productivity of the employees' work. }\end{array}$ & \multirow[t]{4}{*}{$\begin{array}{l}\text { (Kim et al., 2012; } \\
\text { Ryan et al., 2002; } \\
\text { Sabherwal, 1999) }\end{array}$} \\
\hline & & & Reflective & BDAID2 & $\begin{array}{l}\text { When we make big data analytics investment decisions, we consider and project about } \\
\text { how much these options will help end-users make quicker decisions. }\end{array}$ & \\
\hline & & & Reflective & BDAID3 & $\begin{array}{l}\text { When we make big data analytics investment decisions, we think about and estimate the } \\
\text { cost of training that end-users will need. }\end{array}$ & \\
\hline & & & Reflective & BDAID4 & $\begin{array}{l}\text { When we make big data analytics investment decisions, we consider and estimate the } \\
\text { time managers will need to spend overseeing the change. }\end{array}$ & \\
\hline & & \multirow{4}{*}{$\begin{array}{l}\text { Big data } \\
\text { analytics } \\
\text { Coordination }\end{array}$} & Reflective & BDACO1 & $\begin{array}{l}\text { In our organization, business analysts and line people meet frequently to discuss } \\
\text { important issues both formally and informally. }\end{array}$ & \multirow{4}{*}{$\begin{array}{l}\text { (Boynton et al., } \\
\text { 1994; DeSanctis } \\
\text { and Jackson, } \\
\text { 1994; Karimi et } \\
\text { al., 2001; Kim et } \\
\text { al., 2012; Li et } \\
\text { al., 2003) }\end{array}$} \\
\hline & & & Reflective & BDACO2 & $\begin{array}{l}\text { In our organization, business analysts and line people from various departments } \\
\text { frequently attend cross-functional meetings. }\end{array}$ & \\
\hline & & & Reflective & BDACO3 & $\begin{array}{l}\text { In our organization, business analysts and line people coordinate their efforts } \\
\text { harmoniously. }\end{array}$ & \\
\hline & & & Reflective & BDACO4 & $\begin{array}{l}\text { In our organization, information is widely shared between business analysts and line } \\
\text { people so that those who make decisions or perform jobs have access to all available } \\
\text { know-how. }\end{array}$ & \\
\hline & & \multirow{4}{*}{$\begin{array}{l}\text { Big data } \\
\text { analytics } \\
\text { Control }\end{array}$} & Reflective & BDACT1 & In our organization, the responsibility for big data analytics development is clear. & \multirow{4}{*}{$\begin{array}{l}\text { (Karimi et al., } \\
\text { 2001; Kim et al., } \\
\text { 2012) }\end{array}$} \\
\hline & & & Reflective & BDACT2 & We are confident that big data analytics project proposals are properly appraised. & \\
\hline & & & Reflective & BDACT3 & We constantly monitor the performance of the big data analytics function. & \\
\hline & & & Reflective & BDACT4 & Our analytics department is clear about its performance criteria. & \\
\hline
\end{tabular}


IMPACTS OF BUSINESS ANALYTICS CAPABILITY ON FIRM PER-FORMANCE

\begin{tabular}{|c|c|c|c|c|c|c|}
\hline \multirow{12}{*}{$\begin{array}{l}\text { Big data } \\
\text { analytics } \\
\text { technology } \\
\text { capability } \\
\text { (BDATEC) }\end{array}$} & \multirow{12}{*}{$\frac{\frac{i}{3}}{\frac{0}{0}}$} & \multirow{4}{*}{ Connectivity } & Reflective & BDACN1 & $\begin{array}{l}\text { Compared to rivals within our industry, our organization has the foremost available } \\
\text { analytics systems. }\end{array}$ & \multirow{4}{*}{$\begin{array}{l}\text { (Duncan, 1995; Kim et } \\
\text { al., 2012; Terry Anthony } \\
\text { Byrd, 2000) }\end{array}$} \\
\hline & & & Reflective & BDACN2 & $\begin{array}{l}\text { All remote, branch, and mobile offices are connected to the central office for } \\
\text { analytics. }\end{array}$ & \\
\hline & & & Reflective & BDACN3 & $\begin{array}{l}\text { Our organization utilizes open systems network mechanisms to boost analytics } \\
\text { connectivity. }\end{array}$ & \\
\hline & & & Reflective & BDACN4 & $\begin{array}{l}\text { There are no identifiable communications bottlenecks within our organization when } \\
\text { sharing analytics insights. }\end{array}$ & \\
\hline & & \multirow{4}{*}{ Compatibility } & Reflective & BDACM1 & $\begin{array}{l}\text { Software applications can be easily transported and used across multiple analytics } \\
\text { platforms. }\end{array}$ & \multirow{4}{*}{$\begin{array}{l}\text { (Duncan, 1995; Kim et } \\
\text { al., 2012; Terry Anthony } \\
\text { Byrd, 2000) }\end{array}$} \\
\hline & & & Reflective & BDACM2 & Our user interfaces provide transparent access to all platforms and applications. & \\
\hline & & & Reflective & BDACM3 & $\begin{array}{l}\text { Analytics-driven information is shared seamlessly across our organization, regardless } \\
\text { of the location. }\end{array}$ & \\
\hline & & & Reflective & BDACM4 & $\begin{array}{l}\text { Our organization provides multiple analytics interfaces or entry points for external } \\
\text { end-users. }\end{array}$ & \\
\hline & & \multirow{4}{*}{ Modularity } & Reflective & BDAMD1 & Reusable software modules are widely used in new analytics model development. & \multirow{4}{*}{$\begin{array}{l}\text { (Broadbent et al., 1999; } \\
\text { Duncan, 1995; Kim et } \\
\text { al., 2012; Terry Anthony } \\
\text { Byrd, 2000) }\end{array}$} \\
\hline & & & Reflective & BDAMD2 & End-users utilize object-oriented tools to create their own analytics applications. & \\
\hline & & & Reflective & BDAMD3 & $\begin{array}{l}\text { Object-oriented technologies are utilized to minimize the development time for new } \\
\text { analytics applications. }\end{array}$ & \\
\hline & & & Reflective & BDAMD4 & Applications can be adapted to meet a variety of needs during analytics tasks. & \\
\hline \multirow{9}{*}{$\begin{array}{l}\text { Big data } \\
\text { analytics } \\
\text { talent } \\
\text { capability } \\
\text { (BDATLC) }\end{array}$} & \multirow{9}{*}{$\frac{\frac{\vec{z}}{\vec{J}}}{\frac{0}{0}}$} & \multirow{4}{*}{$\begin{array}{l}\text { Technical } \\
\text { Knowledge }\end{array}$} & Reflective & BDATK1 & Our analytics personnel are very capable in terms of programming skills. & \multirow{4}{*}{$\begin{array}{l}\text { (Boar, 1995; Broadbent } \\
\text { et al., 1999; Kim et al., } \\
\text { 2012; Lee et al., 1995; } \\
\text { Terry Anthony Byrd, } \\
\text { 2000) }\end{array}$} \\
\hline & & & Reflective & BDATK2 & Our analytics personnel are very capable in terms of managing project life cycles. & \\
\hline & & & Reflective & BDATK3 & $\begin{array}{l}\text { Our analytics personnel are very capable in the areas of data and network management } \\
\text { and maintenance. }\end{array}$ & \\
\hline & & & Reflective & BDATK4 & $\begin{array}{l}\text { Our analytics personnel create very capable decision support systems driven by } \\
\text { analytics. }\end{array}$ & \\
\hline & & \multirow{4}{*}{$\begin{array}{l}\text { Technology } \\
\text { Management } \\
\text { Knowledge }\end{array}$} & Reflective & BDATM1 & Our analytics personnel show superior understanding of technological trends. & \multirow{4}{*}{$\begin{array}{l}\text { (Kim et al., 2012; Terry } \\
\text { Anthony Byrd, 2000; } \\
\text { Tippins and Sohi, 2003) }\end{array}$} \\
\hline & & & Reflective & BDATM2 & Our analytics personnel show superior ability to learn new technologies. & \\
\hline & & & Reflective & BDATM3 & $\begin{array}{l}\text { Our analytics personnel are very knowledgeable about the critical factors for the } \\
\text { success of our organization. }\end{array}$ & \\
\hline & & & Reflective & BDATM4 & $\begin{array}{l}\text { Our analytics personnel are very knowledgeable about the role of big data analytics as } \\
\text { a means, not an end. }\end{array}$ & \\
\hline & & Business & Reflective & BDABK1 & Our analytics personnel understand our organization's policies and plans at a very & (Duncan, 1995; Kim et \\
\hline
\end{tabular}




\section{IMPACTS OF BUSINESS ANALYTICS CAPABILITY ON FIRM PER-FORMANCE}

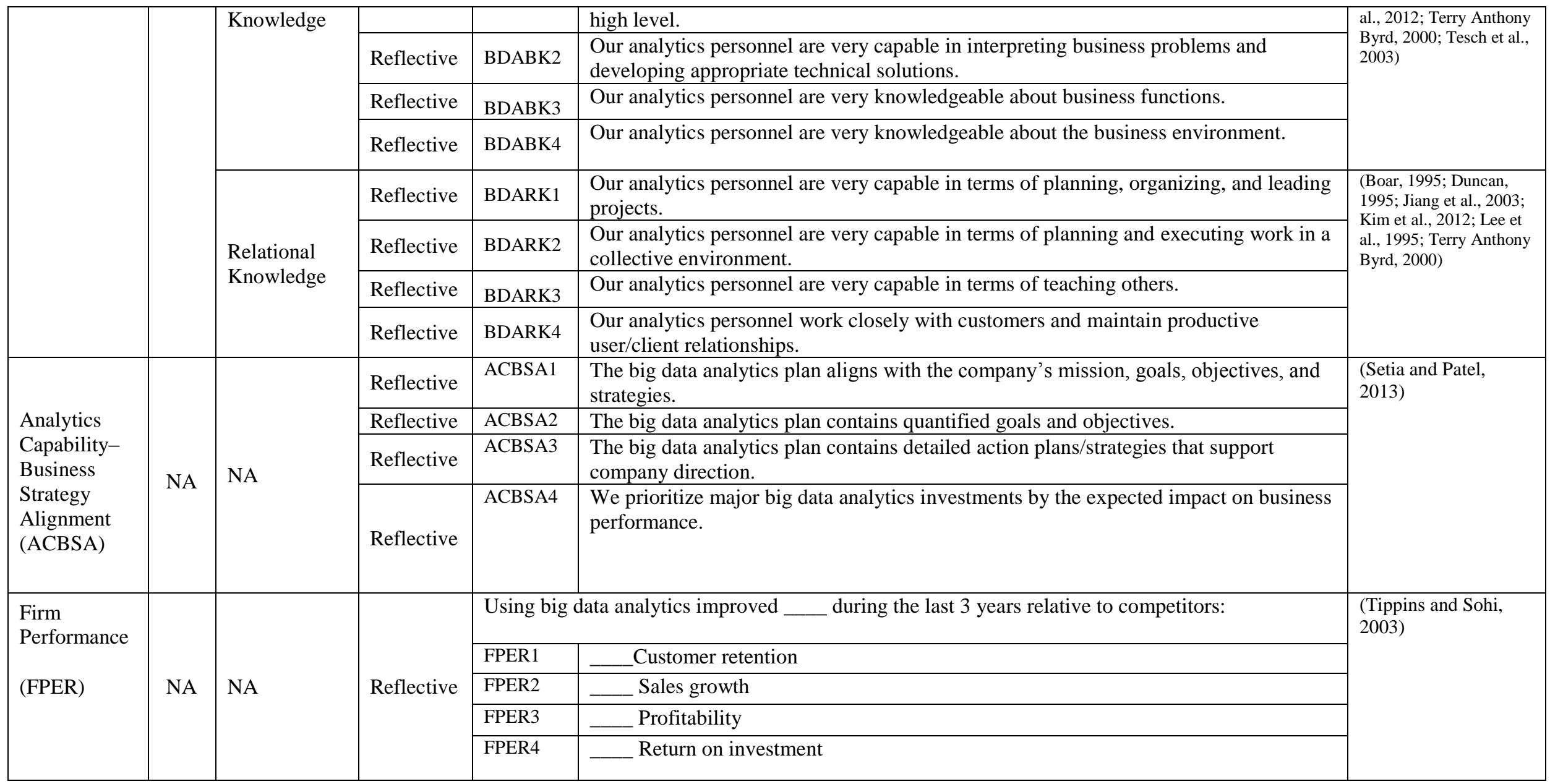


Appendix 2: Structural Model

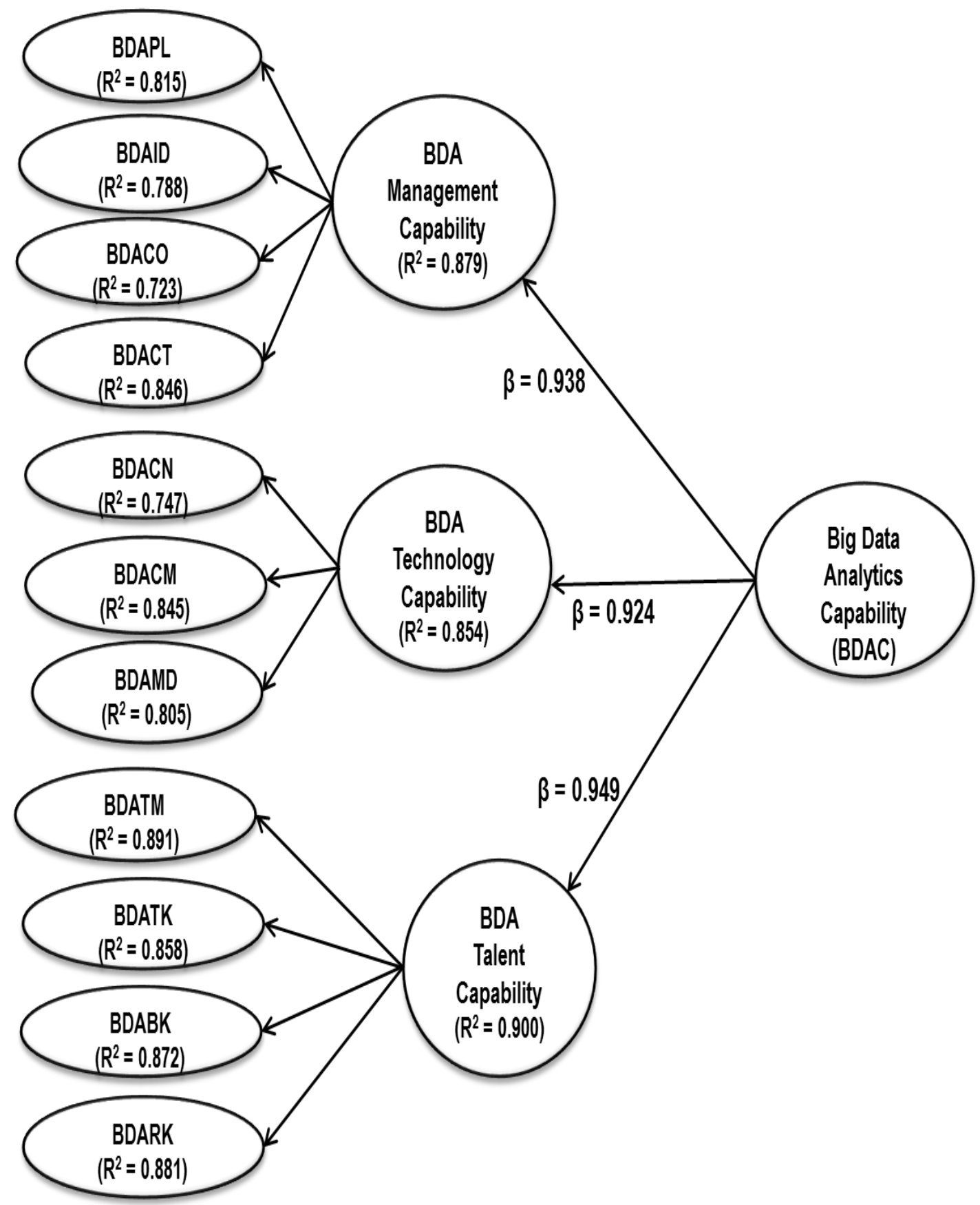

